\title{
In-building waste water heat recovery: urban-scale methods for the characterisation of water streams and the assessment of energy savings and costs
}

\author{
Alexandre Bertrand $^{\mathrm{a}, \mathrm{b}, *}$, Riad Aggoune ${ }^{\mathrm{c}}$, François Maréchal ${ }^{\mathrm{b}}$ \\ ${ }^{a}$ Luxembourg Institute for Science and Technology - LIST, Environmental Research and Innovation, L-4422 Belvaux, \\ Luxembourg \\ ${ }^{b}$ Swiss Federal Institute of Technology of Lausanne - EPFL, Industrial Process and Energy Systems Engineering, \\ CH-1951 Sion, Switzerland \\ ${ }^{c}$ Luxembourg Institute for Science and Technology - LIST, Information Technologies for Innovative Services, L-4362 \\ Esch-sur-Alzette, Luxembourg
}

\begin{abstract}
Residential domestic hot water (DHW) energy consumption represented $16 \%$ of the EU household heating demand in 2013. With the improvement of the building envelop, DHW contribution to energy consumption is expected to increase significantly, with values between $20 \%$ to $32 \%$ in single family buildings, and between $35 \%$ to almost $50 \%$ in multifamily buildings. This energy, currently lost to the environment, can be recovered by waste water heat recovery (WWHR) systems inside buildings (in-building solution). However, the characterisation of residential grey water streams at urban scale has barely been addressed. Also, the impact of such solutions on the total heating consumption and the related costs has not been assessed in detail for different types of residential buildings or for urban systems.

The characterisation and geoallocation method of grey water streams as to mass flow and temperature level is therefore addressed. A method to quantify the energy saving potential and costs at urban scale of in-building WWHR systems in residential buildings is also proposed. These methods are applied in two case-studies, first as retrofitting solution in a city in Luxembourg and, second, as optimisation measure for high efficiency residential buildings. Grey water heat recovery would reduce the residential fuel consumption of the city by $6.3 \%$. An integrated approach combining grey water heat recovery for hot water preheating and a heat pump yields up to $28 \%$ and $41 \%$ electricity savings for passive single family houses and multifamily buildings, respectively.

With the detailed characterisation of various grey water streams in function of inhabitant number and end-use occurrence, the quantification of the energy savings and costs through heat recovery is improved. The outcomes of urban energy and cost assessments concerning grey water heat recovery are more specific, as the results at building level are aggregated to the considered geographical scope. The proposed method therefore complements current urban energy and cost assessments with the detailed integration of in-building grey water heat recovery systems.
\end{abstract}

Keywords: Residential grey water characterisation, Streams geoallocation, In-building waste water heat recovery, Urban energy saving and cost assessments

*Corresponding author at: LIST, 41, rue du Brill - L-4422 Belvaux, Luxembourg. Tel: +352 2758881

Email address: alexandre.bertrand@list.lu (Alexandre Bertrand) 


\section{Nomenclature}

$\begin{array}{ll}\text { CCC } & \text { cold composite curve } \\ \text { COP } & \text { coefficient of power } \\ \text { DHW } & \text { domestic hot water } \\ \text { FW } & \text { fresh water } \\ \text { GW } & \text { grey water } \\ \text { HCC } & \text { hot composite curve } \\ \text { HE } & \text { heat exchanger } \\ \text { HW } & \text { hot water } \\ \text { WW } & \text { waste water }\end{array}$

WWHR waste water heat recovery

\section{Symbols}

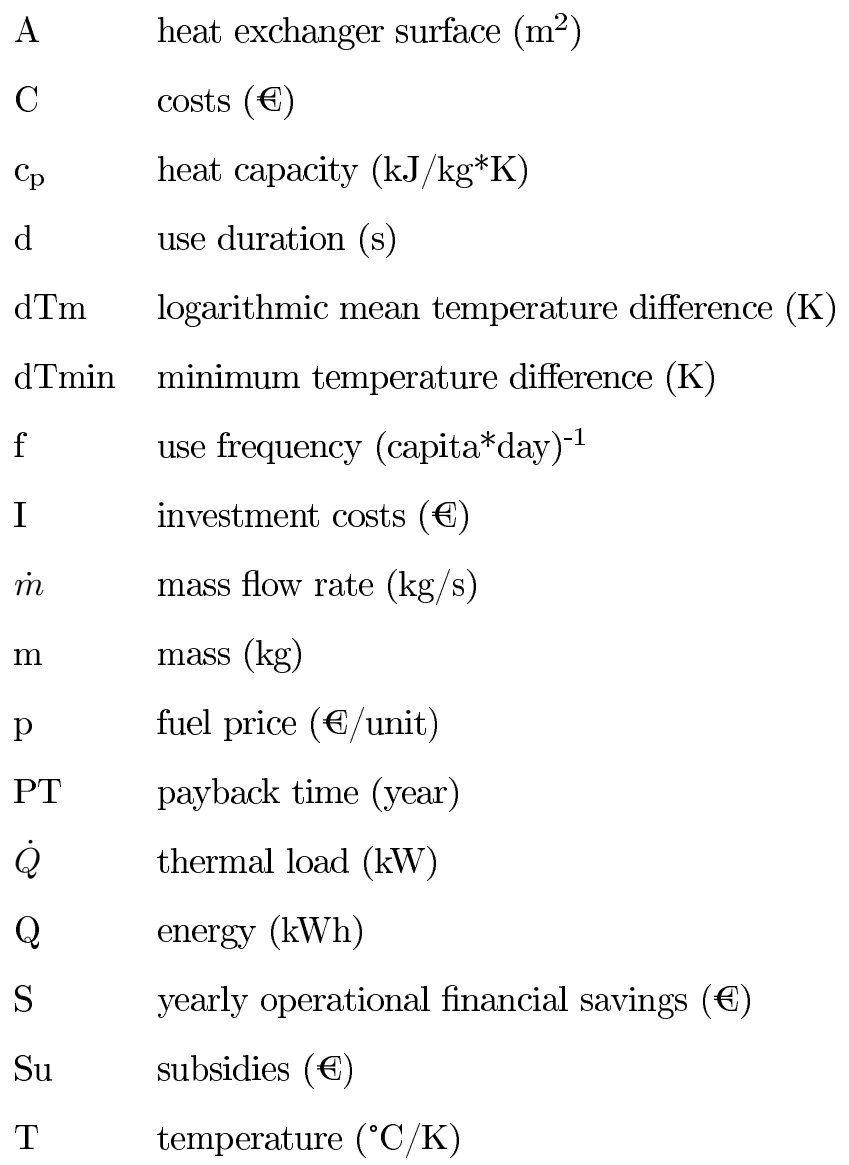




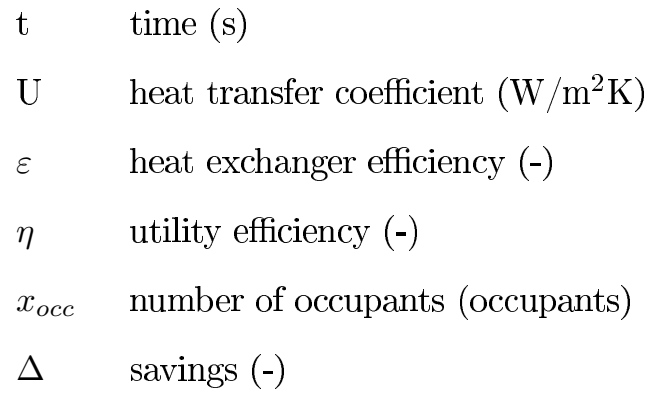

\section{Super- and subscripts}

cond condensation

e end-use

evap evaporation

ins installation

m material

ph preheated

su start-up

to total

u household

\section{Introduction}

In 2014, the European Union (European Commission [1]) decided to reduce its greenhouse gas emissions by $40 \%$ and to improve its energy efficiency by $27 \%$ for 2030 . With a total of 3'441 TWh, $26.8 \%$ of the EU28 final energy consumption in 2013 originated from the household sector, coming only second to transport (31.6\%) (European Commission [2]). Residential domestic hot water (DHW) consumption represented, with $442 \mathrm{TWh}$, approximately 16\% of the EU household heating demand (Enerdata [3]), energy lost with its transfer to the sewers. With the improvement of the building envelop, DHW will have an increasingly important role as to energy consumption, with a contribution to total heating demand between 20 to $32 \%$ in high efficiency single family buildings, and between 35 to almost 50\% in multifamily buildings (Meggers and Leibundgut [4], Bertrand et al. [5]).

An option to reduce DHW-related energy consumption, among water flow reduction devices and temperature level decrease, is to recover, in the building, the heat from the various waste water (WW) streams (in-building solution). The energy saving and cost impacts of shower heat exchangers (HE) have already been assessed (Eslami-nejad and Bernier [6], Wong et al. [7], Guo et al. [8], McNabola and Shields [9]) as well as the combinations of shower heat exchanger with heat pump (Liu et al. [10], Chen et al. [11], Wallin and Claesson [12], Dong et al. [13]) or with solar energy (Liu et al. [10]). Hepbasli et al. [14] conducted a review on heat recovery from residential waste water streams combined with heat pumps. However, specific data on mass flow and temperature level of the various residential WW 
streams is, in general, not given (Meggers and Leibundgut [4]). Characterisation methods applied to waste water stream, considering inhabitant and household number or end-use occurrences, have also not been explored, although the quality of the assessments of waste water heat recovery (WWHR) systems would significantly be improved. In addition, the energy saving or cost impacts of WWHR related to the total heating demand under varying building characteristics (size, period of construction, etc.) were not assessed. The impact of different inhabitant numbers on energy saving and costs of shower HE systems were considered by Meggers and Leibundgut [4] and Kordana et al. [15], but other parameters like building type or varying heating demand according to building age were not addressed. The relevance of these HE systems, both in terms of financial and energy saving impacts, nevertheless changes according to the specificities of the building (e.g. conventional compared to high efficiency buildings). Moreover, methods for the optimal selection and design of heating utilities in buildings considering an integrated approach, as deployed by Girardin et al. [16], Omu et al. [17], Gerber et al. [18], Fazlollahi et al. [19], Jennings et al. [20], include domestic hot water heating requirements, but not waste water heat recovery. In their case-study, Varbanov and Klemes [21] considered the waste water streams of a hotel, but did not include those of the residential area. With the exclusion of waste water heat recovery, the potential of an integrated approach to energy optimisation is therefore not used to its full extend. Finally, the assessment of in-building WWHR at the level of building blocks, districts or a city has been little explored. Leidl and Lubitz [22] and Ni et al. [23] applied a simplified top down approach, i.e. used a 'flat-rate' energy saving value or the result from one building type, respectively. A preliminary version of this work covered only certain WWHR configurations, and costs as well as the impact of energy integration were not considered (Bertrand et al. [24]). More precise results would be obtained by aggregating the energy savings and costs of the specific buildings to the required geographical scale.

Considering these shortcomings, the main objective of this work is to propose a novel method for the characterisation and geoallocation of various residential grey water streams (waste water not loaded with urine and faeces) in function of inhabitant and household number as well as end-use occurrence. Complementary, assessment methods of energy saving and related cost of residential, in-building, grey water heat recovery configurations at urban scale (building block, street, district or city), considering building specificities, are formulated.

The main contribution of the exposed methods is therefore the improvement of the accuracy of integrated energy and cost assessment of in-building grey water heat recovery systems at urban scale.

The proposed characterisation and assessment methods, based on pinch analysis, are described in section 2. These methods are then deployed in two case-studies in section 3. Section 4 discusses the advantages, shortcomings and contributions of the presented work, while conclusions are drawn in section 5 .

\section{Method}

\subsection{Domestic grey water streams characterisation}

Residential DHW end-uses and hot grey water (GW) streams must be characterised as to mass flow, duration and frequency of use per capita. It is also important to define typical temperature levels and to geographically allocate the various end-uses. A review of European DHW end-use models covering these parameters was conducted by Bertrand et al. [5], who proposed a method to characterise and geoallocate these streams as a function of the inhabitant and household numbers in a given urban area.

Similar data on waste water streams is limited (Meggers and Leibundgut [4]). An equation characterising grey water temperatures in function of hot and fresh water (FW) temperatures was proposed by $\mathrm{Ni}$ et al. [23]. However, the quantification of the temperature loss coefficient was not addressed. To characterise grey water streams, the methodology and DHW data described by Bertrand et al. [5] are used here to calculate and geoallocate, by mass balance, the grey water flow, duration and frequency parameters. Water losses during use phase are considered negligible. 


\subsubsection{Bathroom}

Concerning shower streams, Wong et al. [7] provided an equation correlating the drain temperature with outdoor temperatures. However, the method was deployed for Hong-Kong, a humid sub-tropical city, with outdoor temperatures of $15^{\circ} \mathrm{C}$ in winter. This correlation might not be applicable to other climates as it can be expected that in colder climates, the bathroom temperatures remains constant over the year. A limited number of publications provide nevertheless values for shower temperature differences. Eslami-nejad and Bernier [6] mention a difference of $4 \mathrm{~K}$ for Canada, while Wong et al. [7], Guo et al. [8], Dong et al. [13] indicate ranges of 2-5, 5-8 and 6-8 K for China. A difference of $5 \mathrm{~K}$ is used for the heat exchanger certification in Germany (Passivhaus Institut [25]).

No waste water temperature data stemming from baths is indicated in the literature. To obtain an order of magnitude of the temperature decrease a difference between 0.5 and $1.5 \mathrm{~K}$ was measured under different conditions before and after bathing, using a mercury thermometer (tab.1).

Table 1: Bathtub waste water temperatures

\begin{tabular}{lcccc}
\hline $\begin{array}{l}\text { Bath duration } \\
{[\mathrm{min}]}\end{array}$ & $\begin{array}{c}\text { Room } \\
\text { temperature }\left[{ }^{\circ} \mathrm{C}\right]\end{array}$ & $\begin{array}{c}\text { Start } \\
\text { temperature } \\
{\left[{ }^{\circ} \mathrm{C}\right]}\end{array}$ & $\begin{array}{c}\text { End } \\
\text { temperature } \\
{\left[{ }^{\circ} \mathrm{C}\right]}\end{array}$ & $\begin{array}{c}\text { Temperature } \\
\text { difference }[\mathrm{K}]\end{array}$ \\
\hline \hline 20 & 21 & 37.0 & 36.0 & 1 \\
\hline 23 & 22 & 43.0 & 42.5 & 0.5 \\
\hline 26 & 22 & 40.5 & 39.0 & 1.5 \\
\hline 29 & 22 & 38.0 & 36.5 & 1.5 \\
\hline 35 & 22 & 39.0 & 38.0 & 1 \\
\hline
\end{tabular}

It can be assumed that the grey water temperature of the bathroom sink corresponds to that of the DHW stream, as the distance and retention time in the sink are too short to induce a relevant temperature decrease.

\subsubsection{Kitchen}

Concerning dishwashers, not all of the grey water is rejected at high temperature (Saker et al. [26]). For the prewash phase, the water retains its initial, cold, temperature. Grey water temperature levels varying between 34 and $61^{\circ} \mathrm{C}$ for the different washing phases (washing, hot rinsing, cold rinsing, etc.) were given by Paepe et al. [27]. However, this publication may be outdated, as a water consumption of approximately 331 per washing cycle was mentioned by the authors, which is more than twice the water use indicated in other works, e.g. Blokker et al. [28]. Temperature profiles varying between 55 and $60^{\circ} \mathrm{C}$ are provided by several authors (Hoak et al. [29], Hauer and Fischer [30], Persson and Werner [31], Bengtsson et al. [32]), while Jeong and Lee [33] presented the GW energy profile in function of time. Information on according waste water volumes was not provided.

Temperature and water volume profiles for an A rated, 12 places dishwasher from Blomberg/Beko were presented by Saker et al. [26] (tab.2). The water volumes indicated in the table are averaged to simplify the heat recovery calculations. The prewash water is assumed to be transmitted at ambient temperature to the sewer. The washing phase temperature is confirmed by the findings of Richter [34], who observed that $52 \%$ of users select cleaning temperatures at $65^{\circ} \mathrm{C}$ and higher. The energy of the condensing water (drying phase) is negligible compared to the other phases and is therefore not further considered (Jeong and Lee [33]).

Concerning hand dish washing, a certain temperature decrease needs to be considered as the plates are initially at room temperature. As no data is available, it is proposed to consider a difference of 
Table 2: Dishwasher grey water streams characterisation, according to Saker et al. [26]

\begin{tabular}{lcc}
\hline Phase [-] & $\begin{array}{c}\text { Waste water } \\
\text { quantity }[\mathrm{kg}]\end{array}$ & $\begin{array}{c}\text { Waste water } \\
\text { temperature }\left[{ }^{\circ} \mathrm{C}\right]\end{array}$ \\
\hline \hline Wash & 5.0 & 65 \\
\hline Cold rinse & 3.5 & 50 \\
\hline Hot rinse & 4.0 & 45 \\
\hline
\end{tabular}

$5 \mathrm{~K}$. Short uses of the kitchen sink (e.g. hand washing) can be assumed as inducing no temperature losses due to the low duration time.

\subsubsection{Laundry}

Concerning washing machines, Pakula and Stamminger [35] provided data on ownership rate, wash cycle number, water consumption per wash cycle and most frequent wash temperature for several countries and continents $\left(40^{\circ} \mathrm{C}\right.$ in Western Europe). As not all of the machine water is heated up (Saker et al. [26]), national household water consumption statistics to quantify hot grey water volumes must therefore be avoided.

The temperature profile of a washing machine was provided by Persson [36], but the grey water volumes were not given. Ni et al. [23] indicated a hot water (HW) temperature of $49^{\circ} \mathrm{C}$ for this type of equipment. Saker et al. [26] provided water volume and temperature profiles for a mid-range, A rated, $7 \mathrm{~kg}$ washing machine manufactured by Blomberg/Beko. Of the $65 \mathrm{l}$ water used, $10 \mathrm{l}$ are rejected to the sewer at around $37^{\circ} \mathrm{C}$, while the remaining grey water is not particularly hot.

\subsection{Energy assessment of heat recovery configurations from grey water}

Pinch analysis is used here to quantify the heat recovery potential of the various shower and grey water HR configurations for a single family building of 2.98 inhabitants (average number of inhabitants per household from case-study 1). This method, developed by Linnhoff and Flower [37], assesses the heat recovery obtained from cooling down hot streams in order to preheat cold streams. The maximum heat recovery is obtained by defining a minimum temperature difference dTmin between the hot and the cold streams. The results are represented in a load / temperature diagram as represented in fig.1, with the cold composite curve (CCC) as blue, bottom, curve and the hot composite curve (HCC) as red, top, curve. The point where both curves are at the distance of dTmin is the pinch point. The plots are presented here in shifted temperatures, deducing from the real temperature the dTmin contributions of the two streams (here dTmin/2). The overlapping segment of the two curves indicates the heat recovery potential, while the non-overlapping segments represent the remaining cooling (left segment) and heating (right segment) requirements. As complementary outcomes, the exergetic efficicencies of the various configurations are also presented.

\subsubsection{Shower heat recovery configurations}

As input to the pinch analysis calculation, we consider fresh water and sewer temperatures of $10^{\circ} \mathrm{C}$, shower head and tray temperatures of $40^{\circ} \mathrm{C}$ and $35^{\circ} \mathrm{C}$, respectively, and a mean water flow of $0.13 \mathrm{~kg} / \mathrm{s}$. A theoretical dTmin of $3 \mathrm{~K}$ is assumed.

In theory, the DHW shower production could be covered to $74 \%$ by heat recovery when considering fresh and waste water with identical mass flows (balanced flow), with the waste water exiting at $11.5^{\circ} \mathrm{C}$ (temperature at the bottom left point where the two curves do not overlap, fig.1). However, the fresh water temperature would reach $32^{\circ} \mathrm{C}$ instead of the required $40^{\circ} \mathrm{C}$, which implies an further mixing with hot water. This is not feasible, as the maximum fresh water mass flow is already reached. 


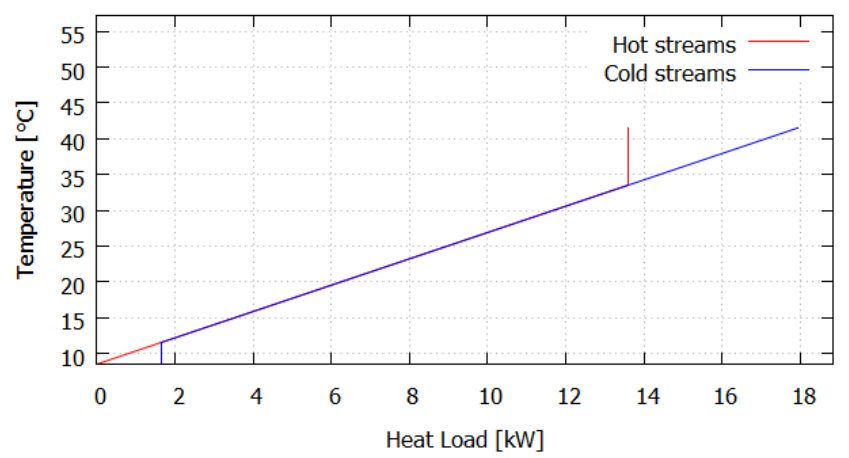

Figure 1: Pinch analysis diagram - balanced conditions

Three concrete configurations are usually considered for the production of shower hot water (Slys and Kordana [38]). The first system (configuration 1) uses the waste water to preheat the hot water flow of the shower (fig.2a). The temperature of $40^{\circ} \mathrm{C}$ is then realised by mixing with cold water. The heat recovery in this configuration only considers the hot water at a lower flow of $0.09 \mathrm{~kg} / \mathrm{s}$. In this case the heat recovery reaches $49 \%$, with the grey water leaving the heat exchanger at $19^{\circ} \mathrm{C}$ instead of $11{ }^{\circ} \mathrm{C}$ (fig.2.b).

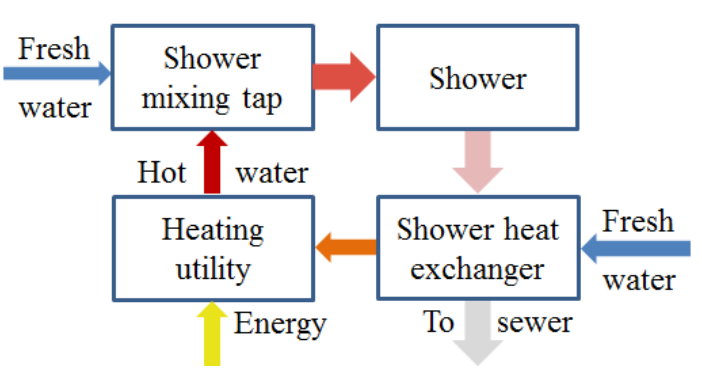

(a) System

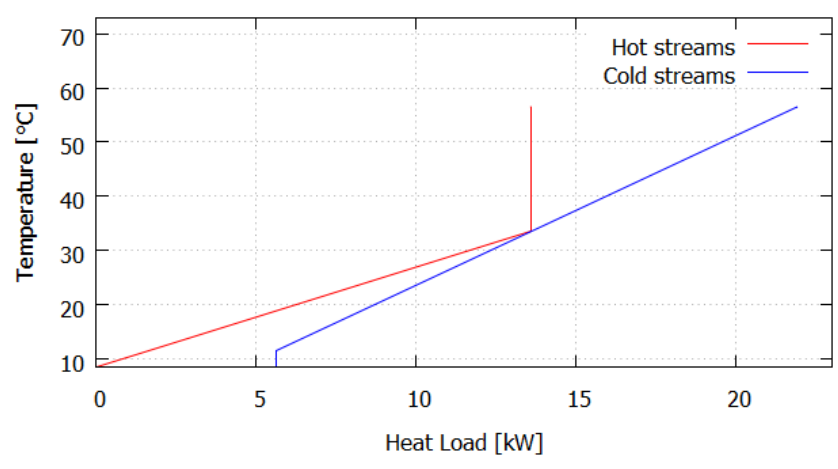

(b) Pinch analysis diagram

Figure 2: Configuration 1

A second option (configuration 2) is to preheat the full shower mass flow of $0.13 \mathrm{~kg} / \mathrm{s}$, and to split it between a preheated 'cold' water stream and a preheated water stream used for hot water production (fig.3a). The heat recovery reaches $74 \%$ and the waste water exits at $11.5^{\circ} \mathrm{C}$ (fig.3b).

In configuration 3 , only the cold water is preheated (fig.4a). The hot water demand is reduced, as the 'cold' water has a higher temperature. Similarly to configuration 1, this configuration is constrained by the cold and hot water mixing, as the mass flow and temperature after mixing must match the shower flow and temperature requirements. After heat recovery, the waste water is at $19{ }^{\circ} \mathrm{C}$ and the heat recovery corresponds to $48 \%$ of the heating load (fig. $4 \mathrm{~b}$ ).

A small minimum temperature difference dTmin of $3 \mathrm{~K}$ and immediate heat transfer are assumed above, in order to compare the efficiency of the various configurations. However, the energy savings by shower heat recovery are also dependent of the heat exchanger type, which influence both heat transfer and duration of the exchange. Actual shower HE are either mounted horizontally in the shower tray 


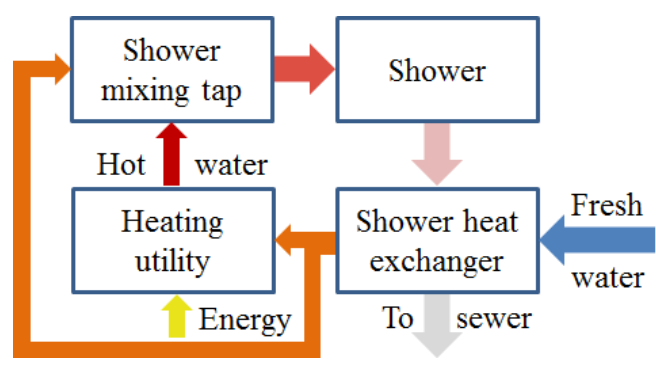

(a) System

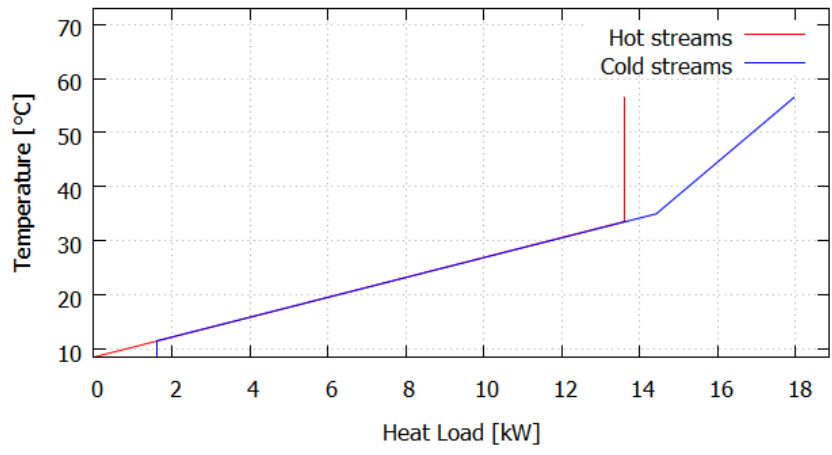

(b) Pinch analysis diagram

Figure 3: Configuration 2

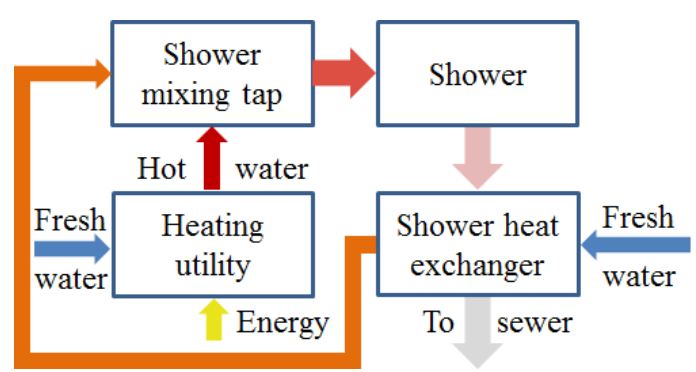

(a) System

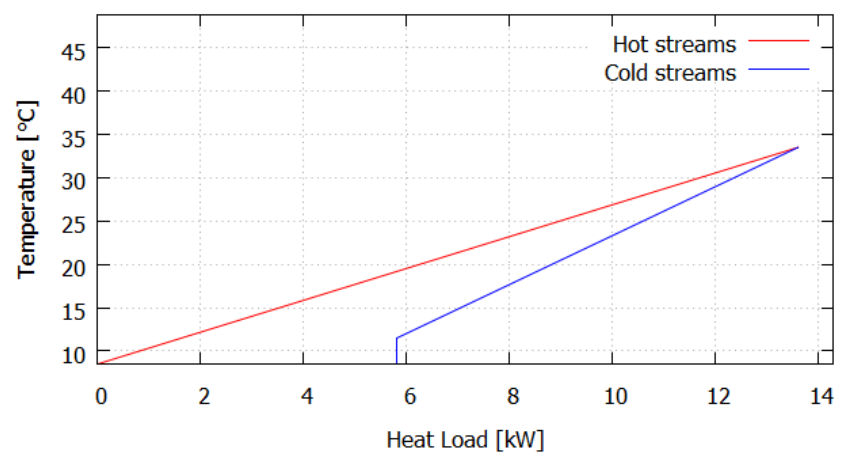

(b) Pinch analysis diagram

Figure 4: Configuration 3

or vertically as element of the waste water piping. Horizontal heat exchangers have a short start-up phase (period where heat exchange does not occur yet) of 5 seconds for the heat exchanger (Passivhaus Institut [39]), while additional 10 seconds for the circulation duration through the shower pipe and tray is further assumed for the present calculations. However, due to their small surface leading to a dTmin between 12-15 K, their heat transfer efficiency is low (balanced flows of $0.13 \mathrm{~kg} / \mathrm{s}$, data source: Wagner Solar GmbH, passiv.de). Vertical HE yield a higher heat recovery efficiency due to a larger exchange surface but the dTmin is still between 9-10 K. Tanha et al. [40] measured a start-up phase of 90 seconds.

The implementation of the different HE and heat recovery configurations is also constrained by space availability, imposed by the building type, and by the location of the heating utility. Vertical HE require one to two meters of space below the shower tray, which limits their installation as retrofit solution in multifamily buildings or single family houses with showers at the ground floor (McNabola and Shields [9]). They are mostly combined with configuration 1 and 2, as the component can be installed close to the heating utility for hot water preheating. Horizontal heat exchangers have lower space requirements and are easily installed, even in existing buildings (Schnieders [41]). They are mostly intended for systems where preheated fresh water is mixed with hot water (configuration 3) and a direct connection to the heating utility is not available. 
Taking into account the actual HE efficiencies and start-up durations as well as implementation constraints, the daily shower energy savings $\Delta Q_{\text {shower }}$, expressed in $\mathrm{kWh}$, can therefore be determined at building level (Eq.(2.1)):

$$
\Delta Q_{\text {shower }}=\frac{\dot{m}^{p h} \times c_{p} \times\left(T^{p h}-T^{F W}\right) \times\left(t_{t o}-t_{s u}\right) \times f \times x_{o c c}}{3600}
$$

with $\dot{m}^{p h}$ the preheated mass flow in $\mathrm{kg} / \mathrm{s}, c_{p}$ the heat capacity in $\mathrm{kJ} / \mathrm{kg} * \mathrm{~K}, T^{p h}$ and $T^{F W}$ the preheated and fresh water temperatures in ${ }^{\circ} \mathrm{C}$, the duration $\left(t_{t o}-t_{s u}\right)$ in $\mathrm{s}$, with $t_{t o}$ being the total and $t_{s u}$ the start-up durations, the daily shower frequency $f$ per person in (day*capita) ${ }^{-1}$ and the number of inhabitants $x_{o c c}$. Values for shower mass flow, duration and frequency in various EU countries are given in Bertrand et al. [5]. The preheated mass flow and temperature variables of the various configurations are obtained by energy and mass balances depending of the considered configuration and heat exchanger type (appendix A).

For the considered household of 2.98 inhabitants, a vertical heat exchanger implemented in configuration 1 and 2 (with estimated $T^{p h}$ of 21 and $26.5^{\circ} \mathrm{C}$ ) yields daily energy savings of 1,0 and 2,2 $\mathrm{kWh}$ /day, respectively, which represents 21 and $45 \%$ of the daily shower energy requirements. The use of a horizontal heat exchanger combined with configuration 3 would result in savings of $1,1 \mathrm{kWh}$. The exergy efficiency of the systems, based on the exergy values on waste water and preheated streams with a reference temperature of $10^{\circ} \mathrm{C}$ and considering the various start-up durations, is $11 \%, 37 \%$ and $15 \%$, respectively.

\subsubsection{Building grey water heat recovery configurations}

The pinch analysis at building level is conducted with the streams described in tab.3, where it is assumed that the building is equipped with a bathtub and a dishwasher.

Table 3: Domestic hot and grey water streams

\begin{tabular}{lccccccc}
\hline Stream [-] & $\begin{array}{c}\text { Appliance } \\
{[-]}\end{array}$ & $\begin{array}{c}\text { Use level } \\
{[-]}\end{array}$ & $\begin{array}{c}\text { End-use } \\
\text { tempera- } \\
\text { ture } \\
{\left[{ }^{\circ} \mathrm{C}\right]}\end{array}$ & $\begin{array}{c}\text { Drain } \\
\text { tempera- } \\
\text { ture } \\
{\left[{ }^{\circ} \mathrm{C}\right]}\end{array}$ & $\begin{array}{c}\text { Mass flow } \\
{[\mathrm{kg} / \mathrm{s}]}\end{array}$ & $\begin{array}{c}\text { Duration } \\
{[\mathrm{s} / \text { capita* }} \\
\text { day }]\end{array}$ & $\begin{array}{c}\text { Frequency } \\
{[1 / \text { capita*day }]} \\
{\left[1 / \text { hhold*day }^{*}\right.}\end{array}$ \\
\hline \hline Hand wash & $\begin{array}{c}\text { Kitchen } \\
\text { sink }\end{array}$ & Household & 35 & 35 & 0.08 & 15 & 3.15 \\
\hline $\begin{array}{l}\text { Washing and } \\
\text { shaving }\end{array}$ & $\begin{array}{c}\text { Bathroom } \\
\text { sink }\end{array}$ & Inhabitant & 35 & 35 & 0.04 & 40 & 1.35 \\
\hline Shower & Shower & Inhabitant & 40 & 35 & 0.13 & 510 & 0.70 \\
\hline Bath & Bath & Inhabitant & 40 & 39 & 0.20 & 600 & 0.044 \\
\hline Wash & Dish washer & Inhabitant & n.a. & 65 & $0.08(5 \mathrm{~kg})$ & 60 & 0.3 \\
\hline Cold rinse & Dish washer & Inhabitant & n.a. & 50 & 0.06 & 60 & 0.3 \\
\hline Hot rinse & Dish washer & Inhabitant & n.a. & 45 & $0.07(4 \mathrm{~kg})$ & 60 & 0.3 \\
\hline Cloth washing & $\begin{array}{l}\text { Washing } \\
\text { machine }\end{array}$ & Household & n.a. & 37 & 0.17 & 60 & 0.45 \\
\hline
\end{tabular}

n.a. - not applicable

Pinch analysis was initially developed for industrial processes, considering continuous operation. 
For the heat recovery analysis conducted here, it is necessary to consider mean flows of water representing the mean power over its time of use. The DHW, grey water and hot water stream loads are therefore obtained by summing the daily energy values and averaging these over one hour, as expressed in Eq.2.2-2.4.

$$
\begin{gathered}
\dot{Q}_{e}=\frac{\sum_{x_{\text {hhold }}} \sum_{x_{o c c}}\left(\dot{m}_{e} \times d_{e} \times f_{e}\right) \times c_{p} \times\left(T_{e}-T^{F W}\right)}{3600} \\
\dot{Q}^{G W}=\frac{\sum_{x_{\text {hhold }}} \sum_{x_{o c c}}\left(\dot{m}_{e}^{G W} \times d_{e} \times f_{e}\right) \times c_{p} \times\left(T^{G W}-T^{\text {sewer }}\right)}{3600} \\
\dot{Q}^{H W}=\frac{\sum_{x_{\text {hhold }}} \sum_{x_{o c c}}\left(\dot{m}_{e}^{H W} \times d_{e} \times f_{e}\right) \times c_{p} \times\left(T^{H W}-T^{F W}\right)}{3600}
\end{gathered}
$$

with $x_{o c c}$ and $x_{h h o l d}$ the inhabitant and household numbers, $T_{e}, \dot{m}_{e}, d_{e}$ and $f_{e}$ the temperature, mass flow, duration and frequency of use of the end-uses e, $c_{p}$ the heat capacity and the various fresh water, grey water, sewer and hot water temperatures $T^{F W}, T^{G W}, T^{\text {sewer }}, T^{H W}$. Complementary equations specific to the various configurations assessed below are given in appendix B.

When considering the immediate heat transfer between the specific DHW and WW streams, represented in fig.5, $80 \%$ of the DHW heating load would be covered by heat recovery, with the grey water being rejected at $14^{\circ} \mathrm{C}$. However, DHW demand and WW rejection do not occur simultaneously and a storage (and according control) systems are necessary for heat recovery.

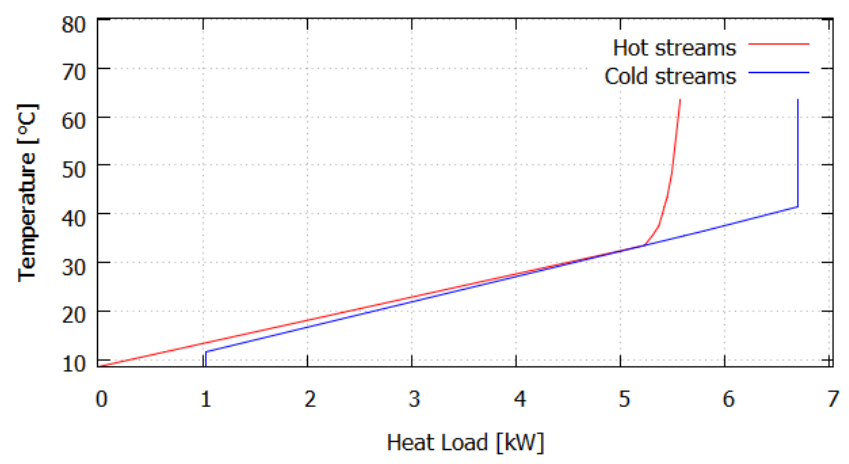

Figure 5: Pinch analysis diagram - DHW and WW streams

One option is to use a grey water storage tank for hot water production (configuration 4, fig.6a). This system reduces the DHW-related energy consumption by $52 \%$. The water is stored at a temperature of $37^{\circ} \mathrm{C}$ and rejected to the sewer at $21^{\circ} \mathrm{C}$ (fig.6b). The exergy efficiency of the system, with $10^{\circ} \mathrm{C}$ as reference temperature, reaches $58 \%$.

Another option is to use a grey water tank for fresh water preheating and a utility producing the DHW only at required temperature (configuration 5, fig.7a). The necessity of hot water production at $55^{\circ} \mathrm{C}$ is linked to hygiene constraints (limitation of Legionella proliferation), but can be avoided in buildings where the volume of the DHW distribution system does not exceed 31 and individual pipes are installed (Brand et al. [42]). With a dishwasher, the actual DHW end-use temperatures do not exceed $40^{\circ} \mathrm{C}$ (Bertrand et al. [5]). The DHW energy consumption can be reduced by $80 \%$, with the grey water rejected at $14^{\circ} \mathrm{C}$ and an exergy efficiency of $88 \%$ (fig. $7 \mathrm{~b}$ ). While yielding a high efficiency, this configuration is difficult to implement, as it requires direct connections between utility and DHW end-uses, which would drastically increase installation and equipment costs.

Finally, grey water streams can also be used for hot water production and storage (configuration 


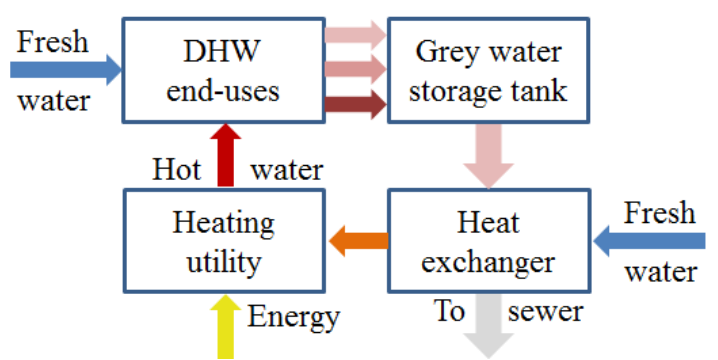

(a) System

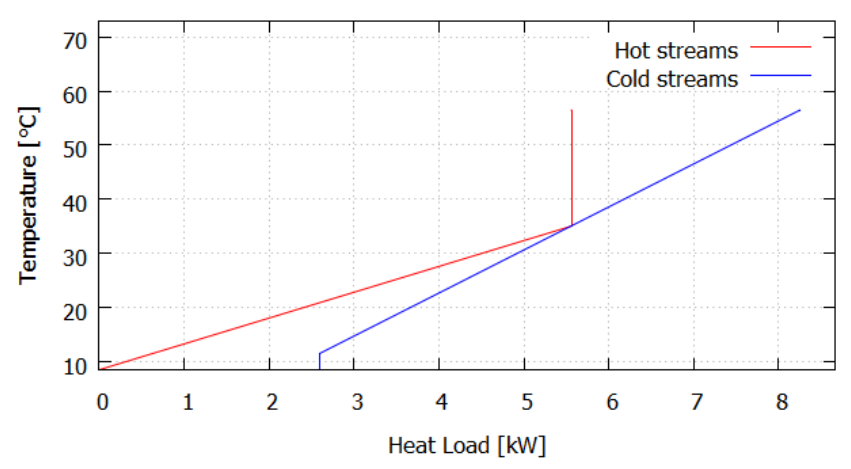

(b) Pinch analysis diagram

Figure 6: Configuration 4

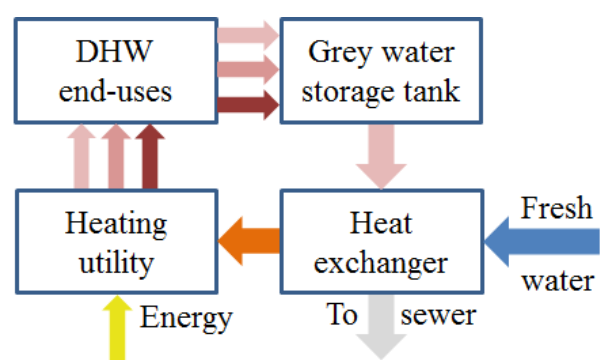

(a) System

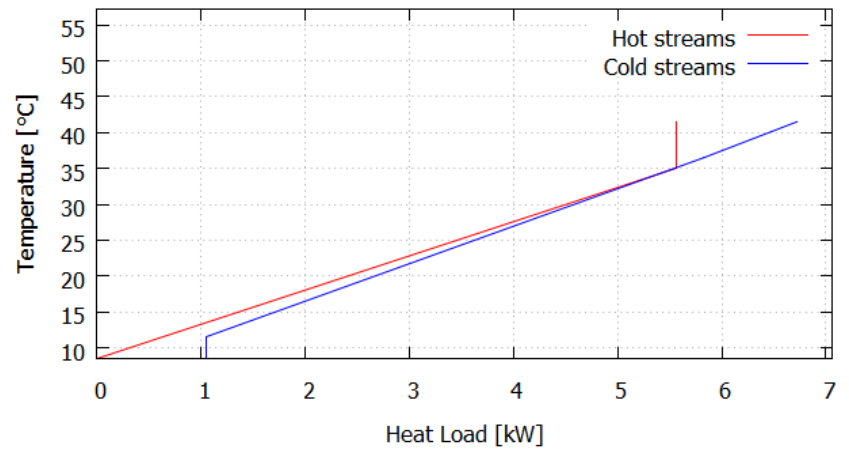

(b) Pinch analysis diagram

Figure 7: Configuration 5

6, fig.8a). For a HW temperature of $55^{\circ} \mathrm{C}$, heat recovery would cover $55 \%$ of the DHW heating, with the grey water streams leaving at a temperature of $20^{\circ} \mathrm{C}$ and a exergy efficiency of the system of $63 \%$ (fig.8b).

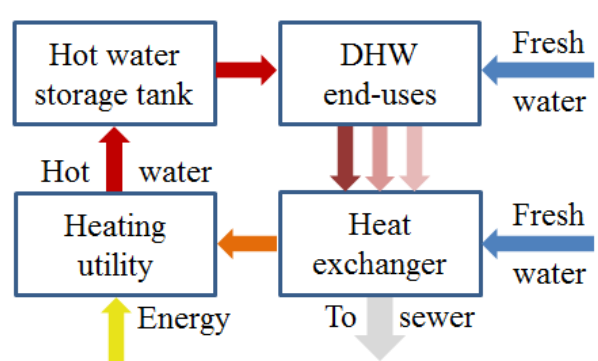

(a) System

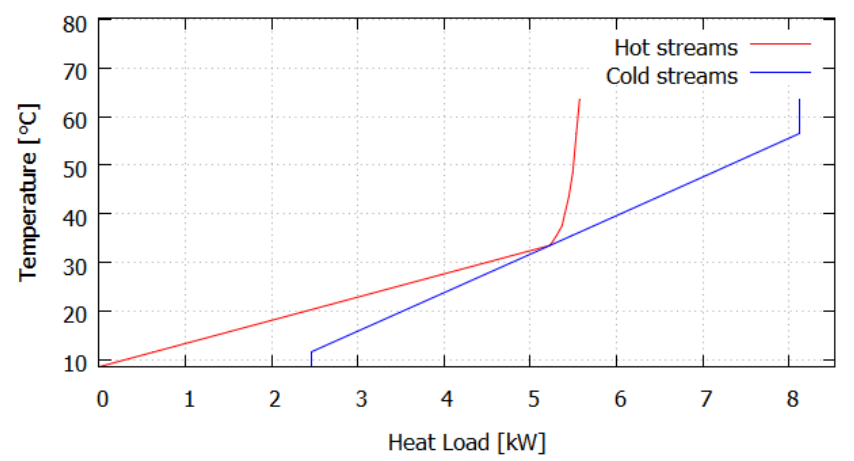

(b) Pinch analysis diagram

Figure 8: Configuration 6 
For urban assessments comprising several buildings, the daily energy savings from grey water heat recovery $\Delta Q_{\text {grey }}$ is computed for each building using the problem table method (Linnhoff and Flower [37]), the algorithmic form of the pinch analysis. The results are then aggregated to the required scale (building block, street, district, city).

\subsection{Costs calculations}

The investment costs I are obtained as the sum of material and installation costs $C_{m}$ and $C_{\text {ins }}$ (Eq.(2.5)).

$$
I=C_{m}+C_{\text {ins }}
$$

For shower heat exchangers, only the additional costs, compared to a normal shower tray or inline drain system, should be considered, to avoid including the cost of the normal drain system.

To calculate the investment costs of the heat exchanger of the grey water configuration, its power is calculated considering the grey water stream with the highest power (usually linked to the bath or the dishwasher) multiplied with a simultaneity factor of 1.15 for single family buildings (Schramek [43]). Concerning multifamily buildings, the simultaneity factor given by Gaderer [44] for DHW demand is multiplied with the sum of the maximum grey water load $\sum_{u} \dot{Q}_{u, \text { max }}^{W W}$, with u the number of households in the building (Eq.(2.6)).

$$
\dot{Q}^{W W, \text { building }}=\left[0.02+0.92 u^{(-0.58)}\right] \times \sum_{u} \dot{Q}_{u, \max }^{W W}
$$

The yearly operation savings $\mathrm{S}$ are proportional to the energy savings $\Delta \mathrm{Q}$, the utility efficiency $\eta$ and the fuel price $\mathrm{p}$ (Eq.(2.7)).

$$
S=\Delta Q \times \eta \times p
$$

The payback time PT in years is the ratio of investment costs I and operating savings $\mathrm{S}$ (Eq.(2.8)).

$$
P T=I / S
$$

The subsidies Su necessary to reach a given payback time PT is finally obtained with Eq.(2.9).

$$
S u=I-(S \times P T)
$$

\section{Case-studies}

Two case-studies, subdivided into several scenarios to assess different optimisation configurations as to their impact on the total heating demand, are deployed in this work. The characterisation as well as energy savings and cost calculation methods are first applied to the existing residential buildings of the city of Esch-sur-Alzette (case-study 1). As the necessary data for the quantification of heating demand of the low energy and passive (high efficiency) residential buildings of the city is not available, and as grey water heat recovery could be of particular relevance for these buildings, these are specifically assessed as to potential energy savings in a second case-study (case-study 2).

\subsection{Common input data}

Temperatures of $10^{\circ} \mathrm{C}$ and $55^{\circ} \mathrm{C}$ are assumed for the fresh and hot water, respectively. The grey water streams are characterised according to section 2.1 and summarised in tab.3. Use frequencies of dishwashers and washing machines are taken from Blokker et al. [28] and Pakula and Stamminger [35] 
respectively. The waste water mass of the streams of these two utilities are considered to be rejected within one minute (Saker et al. [26]).

Two types of heat recovery systems are applied in the case-studies: a horizontal shower heat exchanger (configuration 3) for scenario 1.1 and 2.1 and a grey water heat recovery system for hot water preheating (configuration 6) for scenario 1.2, 2.2 and 2.3, as the majority of the heating systems are equipped with a hot water storage tank (Schramek [43]). The shower heat exchanger is of type Ecoshower 900/ DSS showerdrain channel WWHR model 900/4, with an efficiency of 54\% under steadstate conditions (Passivhaus Institut [39]). With a pipe length of $6.8 \mathrm{~m}$ and an external diameter of $0.016 \mathrm{~m}$ (source: Wagner Solar $\mathrm{GmbH}$ ), the power under unbalanced conditions is 4,86 kW. The fresh water exits the heat exchanger at a temperature of $27^{\circ} \mathrm{C}$ with a mass flow of $0.07 \mathrm{~kg} / \mathrm{s}$. The energy savings related to the grey water heat recovery system are calculated using the problem table method. A minimum temperature difference of $5 \mathrm{~K}$ is considered for the heat exchanger.

\subsection{Retrofit solutions at urban scale}

\subsubsection{Specific input data}

The domestic hot water requirements, based on Geographical Information System data converted into a PostgreSQL database (PostgreSQL [45]), have been characterised in a former work (Bertrand et al. [5]). The occurrence of the various waste water streams are related to the use of the multiple DHW end-uses in each building. $78.8 \%$ of the households are equipped with a dishwasher. The remaining $21.2 \%$ do the dish washing manually, with and end-use temperature of $55^{\circ} \mathrm{C}$, a mass flow of $0.13 \mathrm{~kg} / \mathrm{s}$, a duration of $48 \mathrm{~s}$ and a frequency of 3.15 per household per day (Blokker et al. [28], Schramek [43]). The waste water is assumed to be emitted to sewer at a temperature of $50^{\circ} \mathrm{C}$.

The additional costs of a horizontal shower heat exchanger (scenario 1.1), compared to a normal drain system, are between 150-300 $€$. Average investment costs of $225 €$ are therefore considered for horizontal heat exchangers. Typical installation costs are around 100-300 $€$, an average value of $200 €$ is used here (data source: Wagner Solar GmbH). The investment costs for the grey water heat recovery system (scenario 1.2) are summarised in tab. 4 . The costs for the prefilter, the 3-way valve to avoid cold streams in the storage tank and the sensor are market prices. The specific price of heat exchangers considers a price increase of $50 \%$ to reflect the necessity of a double-wall construction as safety measure to avoid a mixing of grey water with fresh water. Additional piping and installation costs are estimated at $50 €$ and $200 €$, respectively. A utility efficiency of $90 \%$ is applied. The gas price is set to $45.36 \mathrm{c} € / \mathrm{m} 3$, including VAT (source: gas provider Sudgaz, www.sudgaz.lu, last accessed: 21st of January, 2016), with an energy density of $10.5 \mathrm{kWh} / \mathrm{m} 3$. All values are without VAT (3\% for construction projects).

Table 4: Cost parameters for grey water heat recovery

\begin{tabular}{lc}
\hline Component [-] & $\begin{array}{c}\text { Unitary price, excluding } \\
\text { VAT [€] }\end{array}$ \\
\hline \hline Prefilter & 330 \\
\hline Heat exchanger & $45 € / \mathrm{kW}$ \\
\hline 3 way valve & 200 \\
\hline Sensor & 70 \\
\hline Piping & 50 \\
\hline Installation costs & 200 \\
\hline
\end{tabular}




\subsubsection{Results}

3.2.2.1. Energy savings. Figs. 9 (scenario 1.1) and 10 (scenario 1.2) represent the relative energy savings (light blue) and remaining DHW energy requirements (dark blue), related to the total fuel consumption for heating (space heating, DHW, utility inefficiency losses). The percentages indicated are the savings, relative to the total fuel consumption, obtained from the implementation of the HR systems.

With a horizontal heat exchanger, energy savings between 1.4 and $2.2 \%$ in single family buildings, and 3.8 to $5.7 \%$ in multifamily and mixed-use buildings can be reached (fig.9).

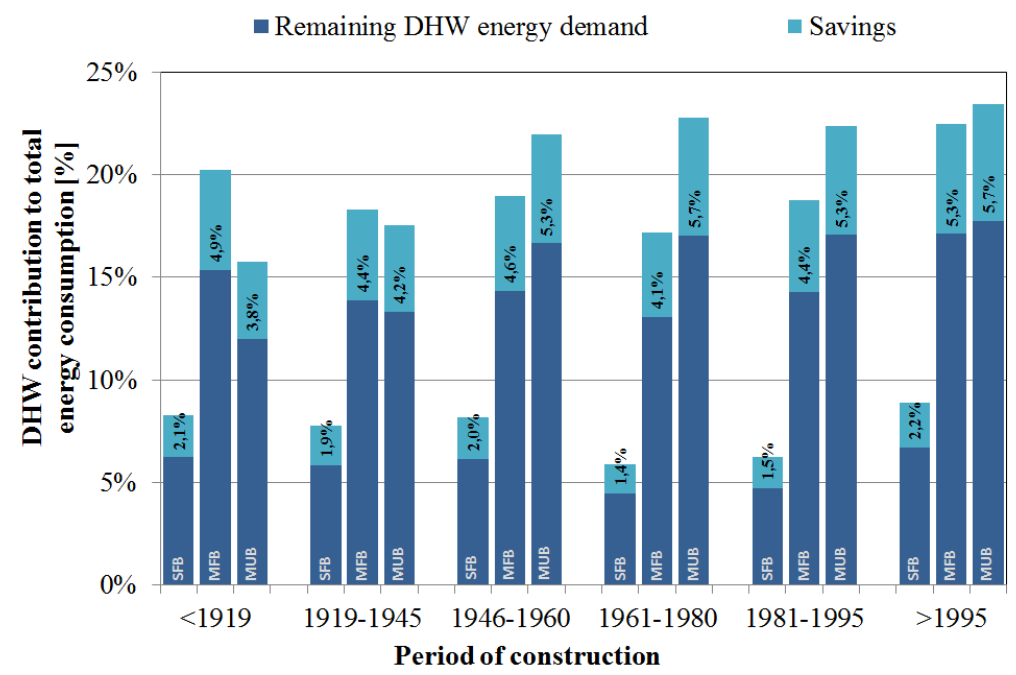

Figure 9: Scenario 1.1: horizontal shower heat exchanger - relative energy savings

With grey water heat recovery for hot water preheating, savings between 3.4 and $5.2 \%$ in single family buildings and between 9.2 and $13.8 \%$ for multifamily and mixed-use buildings are obtained (fig.10).

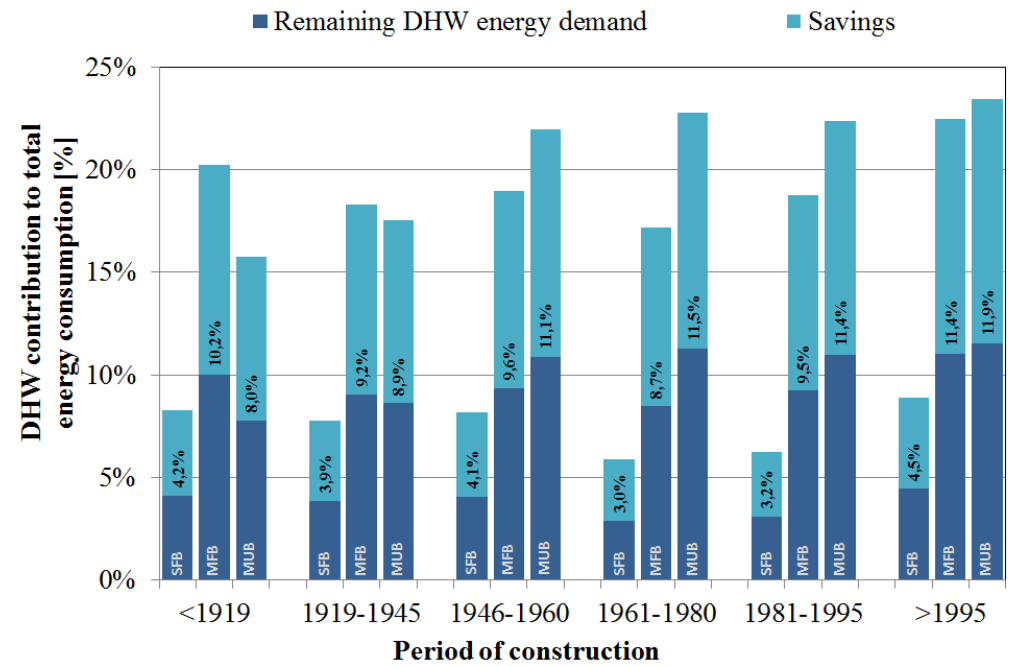

Figure 10: Scenario 1.2: grey water heat recovery - relative energy savings 
3.2.2.2. Payback time. For the assessed heat recovery systems, the investment costs and cost savings depend of the numbers of inhabitants and households. For one-household buildings (fig.11), considering the current natural gas price, shower heat recovery for singles or couples leads to payback times above 50 years, while the average household (three inhabitants), would see a payback time of almost 18 years. From 6 inhabitants on, the payback time falls below 10 years. For the grey water heat recovery of scenario 1.2, the payback time is almost twice as high as scenario 1.1. A payback time of 10 years is reached for households of at least 13 inhabitants. Single family buildings with 12 inhabitants are not occurring in the city and are therefore not displayed. With increasing household numbers per building, the average payback time of shower HR does not change for the households, as displayed for a five households building (fig.12). The payback time for three inhabitants households (15 inhabitants) remains at 18 years. The payback time of grey water heat recovery falls below 10 years for 18 occupants.

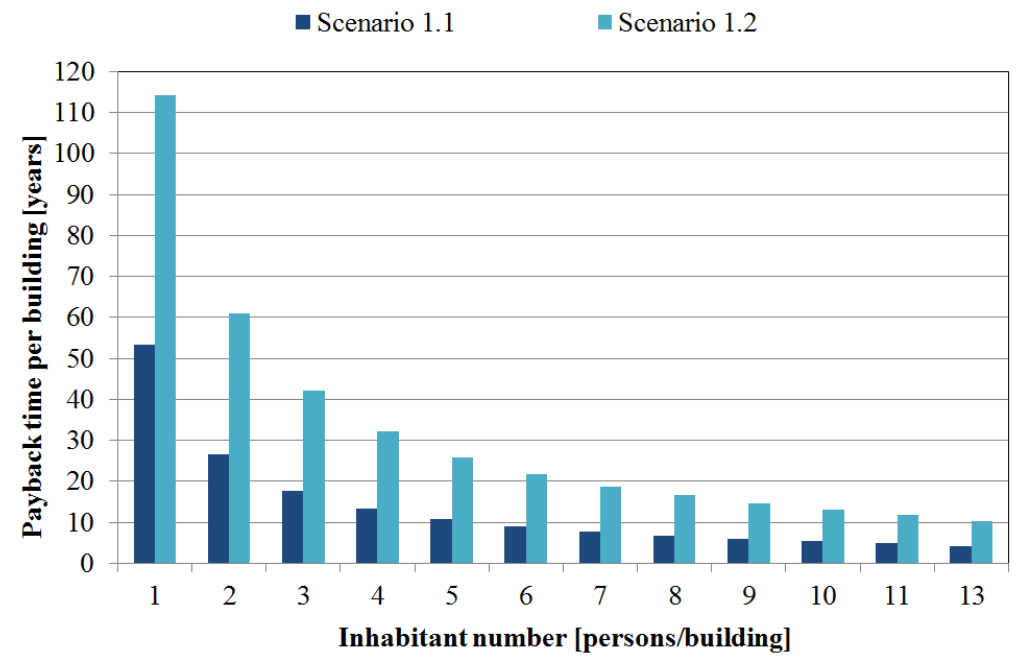

Figure 11: Average payback time for one household buildings

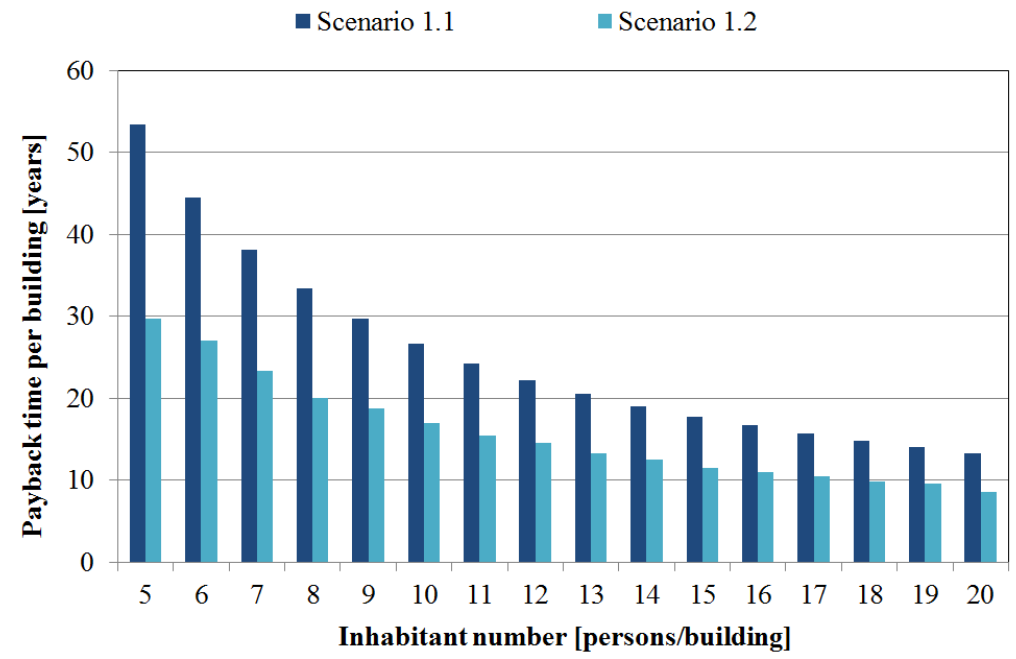

Figure 12: Average payback time for five households buildings 
The direct comparison of these outcomes with the results of similar works is generally not recommended due to strongly varying conditions (e.g. energy prices, equipment and/or installation costs, use frequency and duration). Nevertheless, it should be mentioned that Kordana et al. [15] obtained a payback time for vertical shower heat exchangers of 7, 5 and 4 years for a Polish household with 3, 4 and 5 inhabitants, respectively, and that values between 4 and 5 years for a 4 persons household are calculated by Slys and Kordana [38]. The much lower payback time obtained by these authors can, at least partially, be explained by the considered energy price, which is, with $0.14 € / \mathrm{kWh}$, three times higher than the price used in the present case-study.

With the considered investment costs and actual natural gas price, shower or grey water heat recovery are currently not an economically viable solution in buildings with low inhabitant number. Subsidies from the state or the municipality would therefore be necessary as incentive for the implementation of such energy saving solutions.

3.2.2.3. Assessment at city level. The yearly total heating demand of the residential sector of Esch-surAlzette amounts to $189.2 \mathrm{GWh}$, of which $23.8 \mathrm{GWh}$ is for domestic hot water demand. By aggregating the energy saving and cost results of the various residential buildings to the level of the city, the absolute and relative savings, investment costs, subsidies necessary to reach a payback time of 10 years, and the specific cost per saved kWh of energy are determined (tab.5). The values in brackets are the percentages of subsidies related to the investment costs. With the current energy prices, subsidies of approximately $60 \%$ of the investment costs are required to reach a payback time of 10 years by the inhabitants.

Table 5: Scenario 1.1 and 1.2 energy savings at city scale

\begin{tabular}{lcccccc}
\hline Scenario & $\begin{array}{c}\text { Absolute } \\
\text { energy } \\
\text { savings } \\
{[\text { GWh] }}\end{array}$ & $\begin{array}{c}\text { Relative } \\
\text { energy } \\
\text { savings, } \\
\text { related to } \\
\text { total heating } \\
\text { demand [\%] }\end{array}$ & $\begin{array}{c}\text { Relative } \\
\text { energy savings, } \\
\text { related to } \\
\text { DHW demand } \\
{[\%]}\end{array}$ & $\begin{array}{c}\text { Investment } \\
\text { costs [€] }\end{array}$ & $\begin{array}{c}\text { Subsidies to } \\
\text { reach 10 years } \\
\text { payback time } \\
{[€]}\end{array}$ & $\begin{array}{c}\text { Specific costs } \\
\text { per saved } \\
\text { energy } \\
{[€ / \mathrm{kWh}]}\end{array}$ \\
\hline \hline 1.1 & 5.8 & $3.1 \%$ & $24.3 \%$ & $6^{\prime} 269^{\prime} 018$ & $\begin{array}{c}3^{\prime} 559^{\prime} 414 \\
(57 \%)\end{array}$ & 1.08 \\
\hline 1.2 & 12.0 & $6.3 \%$ & $50.6 \%$ & $1^{\prime} 4^{\prime} 239^{\prime} 324$ & $\begin{array}{c}8^{\prime} 771^{\prime} 601 \\
(62 \%)\end{array}$ & 1.19 \\
\hline
\end{tabular}

The geoallocated energy savings per district are represented for the two scenarios in fig.13.a and b.

\subsection{Energy optimisation of high efficiency residential buildings 3.3.1. Specific input data}

Four scenarios focusing on the energy savings in low energy and passive single and multifamily buildings in Luxembourg are considered in this second case study. The reference scenario 2.0, as applied so far in integrated energy optimisation approaches, includes space heating and hot water demand at $55^{\circ} \mathrm{C}$. The same streams are used for scenario 2.1 , to which the shower waste water stream, for heat recovery with an horizontal heat exchanger, is added. In scenario 2.2, space heating and hot water streams at $55^{\circ} \mathrm{C}$ and all grey water streams listed in tab. 3 are used as input. Scenario 2.3 presents an integrated approach to heating optimisation. Space heating remains identical, while DHW is characterised as $45^{\circ} \mathrm{C}$ hot water and the waste water streams can be cooled down further than $10^{\circ} \mathrm{C}$. 


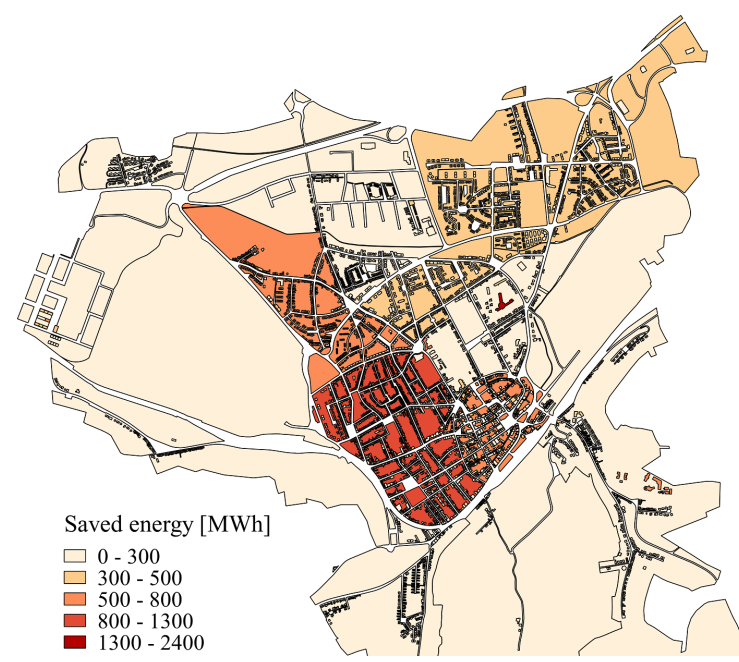

(a) Scenario 1.1: horizontal shower heat exchanger

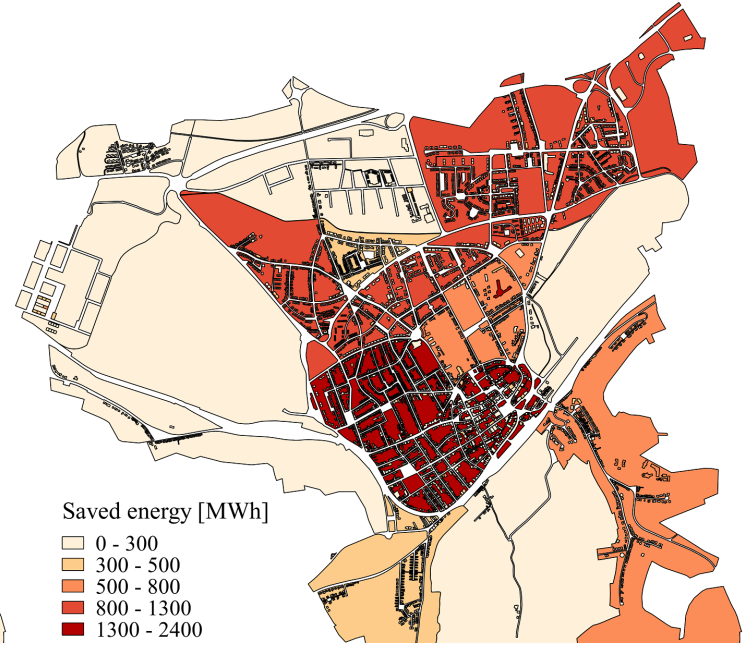

(b) Scenario 1.2: grey water heat recovery

Figure 13: Energy savings per districts

These streams are used as input to the pinch analysis to design the optimal heat recovery and utility system.

The specificities of the considered buildings are summarised in tab. 6 . The average inhabitant and household numbers as well as average surface are taken from the GIS database from Esch-sur-Alzette, while the specific space heating energy consumption is from the Luxembourgish legislation on energy efficient buildings (Luxemburgish Parliament [46]). It is assumed that $100 \%$ of the households are equipped with a washing machine. The space heating nominal load is calculated using the heating signature as described by Girardin et al. [16] and the monthly temperature profile indicated in Luxemburgish Parliament [46] for a theoretical coldest day $\left(-10^{\circ} \mathrm{C}\right)$ and average day $\left(7^{\circ} \mathrm{C}\right)$, up to an outdoor temperature of $15^{\circ} \mathrm{C}$.

The electricity consumptions and savings are calculated for three specific periods: winter, intermediate and summer (tab. 7). The period durations have been determined by considering the space heating load and energy requirements of tab. 6, assuming a short duration of 10 hours at minimal outdoor temperature. Floor heating temperature is set to $28 / 35^{\circ} \mathrm{C}$. The temperature of the grey water streams to the sewer does not go below $10^{\circ} \mathrm{C}$ in scenario 2.2 . and $4^{\circ} \mathrm{C}$ (winter), $7^{\circ} \mathrm{C}$ (intermediate period) and $17^{\circ} \mathrm{C}$ (summer) for scenario 2.3 .

The heating utility considered is a two-stage air/water heat pump. The first stage covers water temperature of $35^{\circ} \mathrm{C}$ for space heating and hot water preheating, with a condensation temperature $T_{\text {cond }}$ of $38^{\circ} \mathrm{C}$, and a second stage for hot water (scenario $2.0,2.1$ and $2.2: 55^{\circ} \mathrm{C}$, scenario $2.3: 45^{\circ} \mathrm{C}$ ), with condensing temperatures of $58^{\circ} \mathrm{C}$ (scenario 2.0 and 2.1), $60^{\circ} \mathrm{C}$ (scenario 2.2, considering a dTmin of $5 \mathrm{~K}$ for the grey water heat exchanger) and $48^{\circ} \mathrm{C}$ (scenario 2.3). For scenario 2.0., 2.1 and 2.2, the evaporation temperature $T_{\text {evap }}$ is $3 \mathrm{~K}$ below outdoor temperature. For scenario 2.3 , the remaining heat going to the sewer is used as partial heat source for the evaporation side of the heat pump (see tab. 7 for the considered temperature levels). The remaining heat source for evaporation is air. Finally, the coefficient of power (COP), to calculate the electricity consumption, is obtained with Eq. 3.1, considering an exergy efficiency rate of $34 \%$ (Girardin et al. [16]).

$$
C O P=\eta \times \frac{T_{\text {cond }}}{T_{\text {cond }}-T_{\text {evap }}}
$$


Table 6: Case-study 2: building characteristics

\begin{tabular}{|c|c|c|c|c|}
\hline Building type & \multicolumn{2}{|c|}{ Single family building } & \multicolumn{2}{|c|}{ Multifamily building } \\
\hline Total surface $\left[\mathrm{m}^{2}\right]$ & \multicolumn{2}{|c|}{166} & \multicolumn{2}{|c|}{512} \\
\hline $\begin{array}{l}\text { Inhabitant number } \\
\text { [inhabitant] }\end{array}$ & \multicolumn{2}{|c|}{3} & \multicolumn{2}{|c|}{12} \\
\hline $\begin{array}{l}\text { Household number } \\
\text { [household] }\end{array}$ & \multicolumn{2}{|c|}{1} & \multicolumn{2}{|c|}{5.5} \\
\hline $\begin{array}{l}\text { Domestic hot water } \\
\text { energy demand } \\
\text { [kWh/a] }\end{array}$ & \multicolumn{2}{|c|}{$1 ' 128$} & \multicolumn{2}{|c|}{$4^{\prime} 584$} \\
\hline Efficiency type & Low energy & Passive & Low energy & Passive \\
\hline $\begin{array}{l}\text { Specific space } \\
\text { heating energy } \\
\text { demand }\left[\mathrm{kWh} / \mathrm{m}^{2}\right]\end{array}$ & 43 & 22 & 27 & 14 \\
\hline $\begin{array}{l}\text { Total space heating } \\
\text { energy demand } \\
{[\mathrm{kWh}]}\end{array}$ & 7'123 & 3'644 & $13 ’ 816$ & $7^{\prime} 164$ \\
\hline $\begin{array}{l}\text { Space heating } \\
\text { maximal load [kW] }\end{array}$ & 3.6 & 1.8 & 7.0 & 3.6 \\
\hline $\begin{array}{l}\text { Space heating } \\
\text { intermediate load } \\
{[\mathrm{kW}]}\end{array}$ & 1.2 & 0.6 & 2.2 & 1.2 \\
\hline
\end{tabular}

Table 7: Case-study 2: operating period characteristics

\begin{tabular}{lccc}
\hline Period & Winter & Intermediate & Summer \\
\hline \hline Duration $[\mathrm{hrs}]$ & 10 & $6^{\prime} 163$ & $2{ }^{\prime} 587$ \\
\hline $\begin{array}{l}\text { Average outdoor } \\
\text { temperature }\left[{ }^{\circ} \mathrm{C}\right]\end{array}$ & -10 & 7 & 17 \\
\hline $\begin{array}{l}\text { Scenario } 2.3 \text { partial } \\
\begin{array}{l}\text { evaporation } \\
\text { temperature }\left[{ }^{\circ} \mathrm{C}\right]\end{array}\end{array}$ & 4 & 10 & 17 \\
\hline
\end{tabular}

\subsubsection{Scenario 2.3: energy integration}

By applying energy integration design rules based on pinch analysis (no heat exchangers across the pinch point, heat pumps must have their evaporation and condensation elements below and above the pinch point (Becker [47])) to detect optimal heat recovery and utility design configuration, the energy consumption for the optimised scenario 2.3 is calculated. The hot and cold composite curves of the energy integration for the single family, low energy, building are represented in fig. 14 for the three periods. The horizontal segments of the hot streams curves represent the condensation loads of the heat pump. The horizontal segment of the cold streams is the evaporation load. The pinch point, for the four building types, is situated at $29.5^{\circ} \mathrm{C}$ for the winter and intermediate periods, and $33.5^{\circ} \mathrm{C}$ 


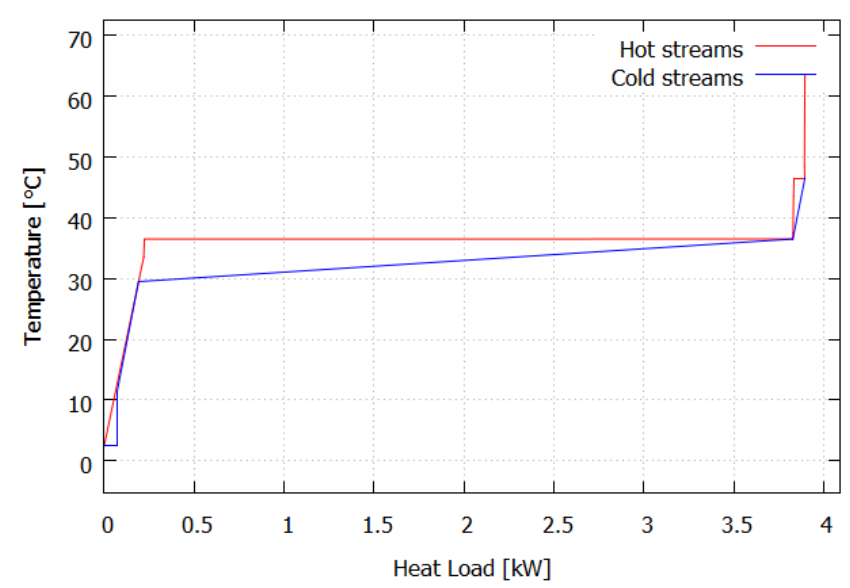

(a) Winter above the pinch point.

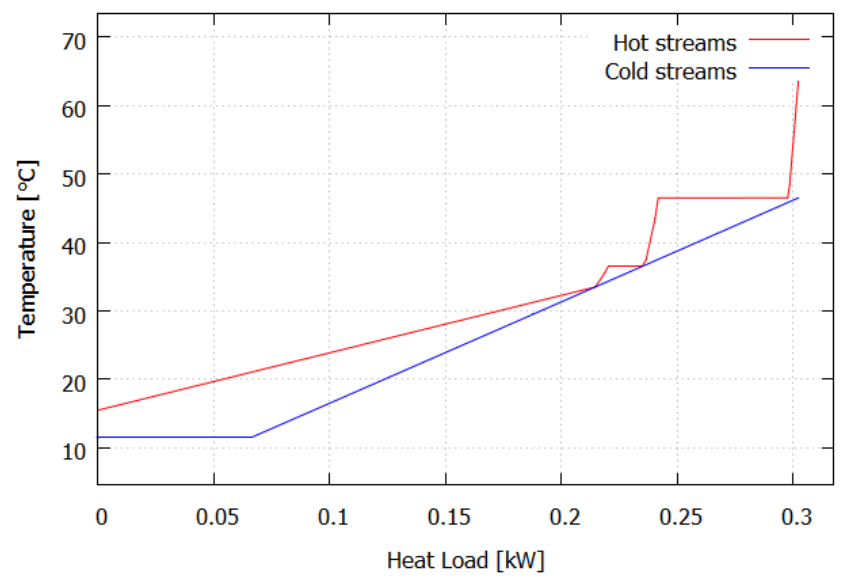

(c) Summer

for the summer period. Heat recovery must therefore be designed with two heat exchangers, one to preheat the cold streams with the hot streams below and one for heat transfer between the streams

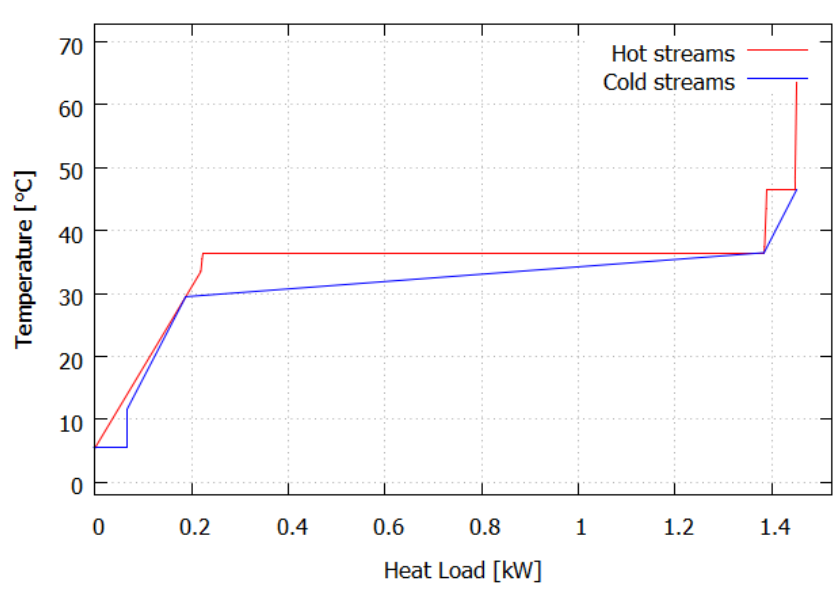

(b) Intermediate

Figure 14: Scenario 2.3 - Pinch analysis diagram

The heat recovery potential in winter is rather limited ( $4 \%$ of the total power) due to the relevance of the space heating requirements. However, the waste heat can be fully used for hot water preheating until a temperature of $11.5^{\circ} \mathrm{C}$, then valorised as heat source for the heat pump. During the intermediate period, the grey water is led to the heat pump at a temperature of $14^{\circ} \mathrm{C}$, the waste heat recovery contributing to $11 \%$ of the load. In summer, where no space heating demand occurs, $55 \%$ of the heating load is covered by heat recovery, with the grey water cooled down to $21^{\circ} \mathrm{C}$ before being used by the heat pump. Due to the small load, using the remaining grey water as heat source for the heat pump reduces the electricity consumption only by $1-2 \%$.

\subsubsection{Results}

The results of the various scenarios of case-study 2 are summarised in fig. 15. The percentages indicate the electricity savings related to the electrical consumption for heating. 


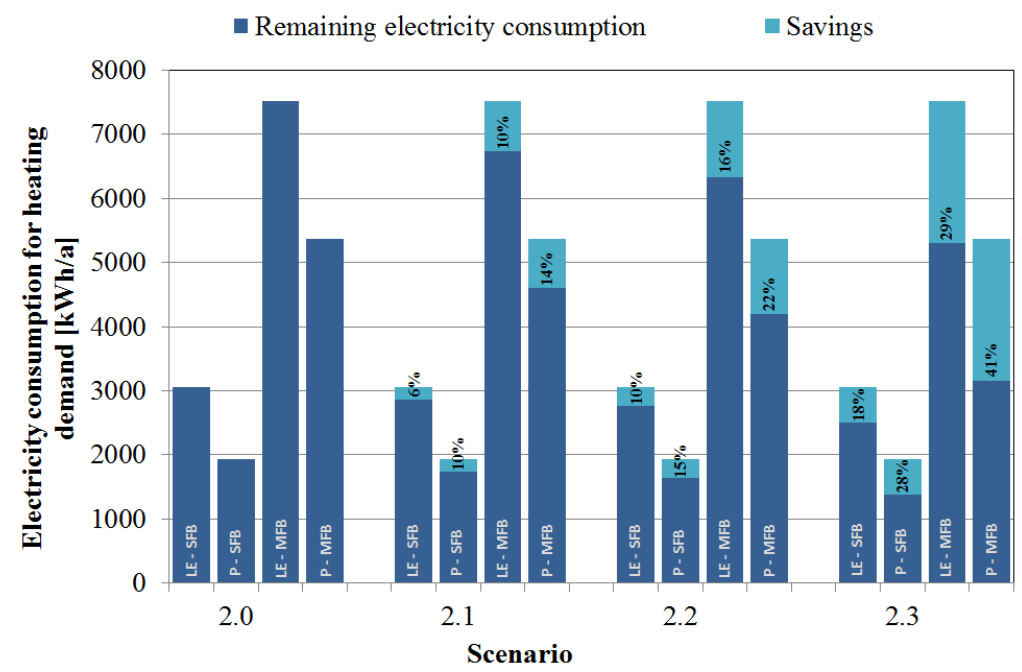

Figure 15: Case-study 2: results (LE - low energy, P - passive, SFB - single family building, MFB - multifamily building)

With the implementation of a horizontal shower heat exchanger, the heating electricity consumption can be reduced between 6 to $14 \%$, according to the building type. The impact of grey water heat recovery on electricity consumption is between 10 to $22 \%$. The integrated approach, where hot water production, heat recovery and utility design are optimised, reduces the electricity consumption between 18 to $41 \%$. As already observed in the first case-study, waste water heat recovery systems have a larger impact in multifamily buildings than in single family houses.

Considering these outcomes, the implementation of grey water heat recovery systems should be included in an energy integration approach to further optimised the energy savings. Moreover, it is demonstrated that energy integration approaches for high efficiency residential buildings, as deployed by e.g. Fazlollahi et al. [19], Jennings et al. [20] and applied in scenario 2.0, should also include waste water streams and hot water demand optimisation to increase the energy optimisation potential.

\section{Discussion}

New, detailed, methods to characterise grey water streams and to assess the energy savings and costs at urban scale from in-building grey water heat recovery in residential buildings are proposed.

One of the main strengths of the deployed work is the detailed characterisation and geoallocation of residential grey water streams as to mass flow and temperature level, in function of inhabitant and household numbers. This characterisation allows a more precise assessment of WWHR potential at urban scale. In addition, WWHR energy savings can be related to buildings specificities, e.g. enduse occurrence, building type, age and energy efficiency. Their impact can therefore be calculated in reference to the total heating demand, thus supporting decision processes as to the selection and design of appropriate energy saving measures in buildings. Furthermore, the energy savings and costs are attributed to each specific building in the considered geographical scope. Results can easily be generated at specific spatial levels (building blocks, streets, districts city). The outcomes of urban energy assessments considering WWHR are thus improved, as the large-scale results are obtained by data aggregation. Finally, it is also demonstrated that an integrated approach to heating system selection and design must include hot water demand and grey water streams to further optimise energy consumption. 
One limitation of the exposed work consists in the low availability and poor technical, geographical and socio-economic detail level of the input data. Knowledge of the occurrence of retrofitting constraints, which influences configuration selection at urban level, is also limited. The proposed calculation methods are also simplified to accommodate the problem scale and do not reflect thermal losses by distribution, transient conditions of storage systems or long-term efficiency drop of the heat exchangers, which further reduce the energy saving potential. Moreover, the urban assessment of casestudy 1 and the integrated solution deployed in case-study 2 do not include other systems (e.g. sewer heat recovery, solar thermal collectors), which could, potentially, further improve the optimisation potential.

Concerning data availability, mass flow and temperature data in function of building type and socio-economic level of the household must be further gathered. The use of Geographically Weighted Regression would also improve the quality of the assessment as the geoallocation of certain enduses would better reflect socio-economic conditions. Also, sensitivity analysis shall be applied to the proposed method in order to quantify the uncertainty of the outcomes, as reflected in case-study 1 by the comparison of the payback time values with the results from Kordana et al. [15] and Slys and Kordana [38]. In addition, the occurrence rate of the implementation constraints, in function of building type, must be better characterised, in order to improve the assessment of WWHR systems at urban scale. More detailed calculation methods must also be developed for the considered urban scale, although resolution time might become an issue when assessing very large systems. Finally, the competition between in-building and sewer heat recovery configurations must be assessed at urban scale, in order to select adequate solutions according to district/city age and infrastructure.

The main significances of the present work are the characterisation method of grey water streams and the detailed energy saving and cost assessments methods, considering building specificities and various grey water streams, of residential WWHR potential at urban scale. The exposed methods lead to several contributions in the field of building and urban energy analysis and optimisation.

At building level, residential grey water streams are more specifically characterised by reflecting DHW end-use occurrence as well as inhabitant and household numbers. The assessment for grey water heat recovery potential is therefore qualitatively improved, independently of the configuration (in-building, in-sewer or at waste water treatment plants), which allows a better comparison with other energy saving measures. In addition, the integrated optimal selection of heating utility configurations is extended with the characterisation of the grey water streams as additional source for heat recovery or heat pumps.

At urban scale, energy and cost assessments at building block, district or city levels are qualitatively improved and spatially better differentiated, as the outcomes are generated by results aggregation of the single buildings. Urban energy assessments and optimisation, focusing so far on thermal insulation and heating utility selection, are also expanded to include detailed grey water heat recovery as additional optimisation measure. The ranking and selection of optimisation scenario by decision takers are improved by relating the impact of these different measures to the total heating demand.

A priority for future works should be the sensitivity analysis of the grey water stream characterisation as well as the quantitative improvement of input data. Also, in-sewer and waste water treatment plant heat recovery configurations should be included in the urban energy and cost assessment methods, in order to compare the advantages and disadvantages of centralised and decentralised WWHR. Finally, with the large number of potential design parameters and in-building but also sewer heat recovery configurations, an integrated, multi-objective, selection method as optimisation problem, using e.g. Mixed Integer Linear Programming, to detect optimal heat recovery, storage and heating utility systems is necessary. 


\section{Conclusions}

With the detailed characterisation of residential hot grey water streams, the quantification of costs and energy savings through heat recovery is improved qualitatively. The energy savings and payback times of in-building WWHR systems can be more precisely compared with other optimisation measures. The aggregation of the energy savings and costs from the single buildings to the urban scale also allows to improve the results of large-scale energy assessments concerning grey water heat recovery. The present work thus contributes to the EU greenhouse gas emission reduction as well as energy efficiency improvement targets, especially concerning near-zero energy buildings.

\section{Acknowledgements}

This work is supported by the Luxembourgish National Research Fund, grant agreement AFR 5775018 "OptiHeat". The authors would like to thank the municipality of Esch-sur-Alzette, the energy provider Sudstroum and the national statistic agency Statec for their support concerning the casestudy, as well as Fabian Schröer from Wagner Solar GmbH for his input on shower heat recovery systems. Alessio Mastrucci from LIST, as well as Nils Schüler and Jean-Loup Robineau from EPFL are kindly acknowledged for their valuable inputs.

\section{AppendixA. Mass and temperature levels for shower heat recovery configurations}

\section{Configuration 1}

The preheated mass flow $\dot{m}^{p h}$ corresponds to the hot water mass flow $\dot{m}^{H W}$, obtained by considering mass (Eq.(A.1)) and energy (Eq.(A.2)) conservation equations, with the temperatures expressed in K (Eq.(A.3)).

$$
\begin{gathered}
\dot{m}_{\text {shower }}=\dot{m}^{H W}+\dot{m}^{F W} \\
T_{\text {shower }} \times \dot{m}_{\text {shower }}=T^{H W} \times \dot{m}^{H W}+T^{F W} \times \dot{m}^{F W} \\
\dot{m}^{H W}=\dot{m}_{\text {shower }} \times \frac{\left(T_{\text {shower }}-T^{F W}\right)}{\left(T^{H W}-T^{F W}\right)}
\end{gathered}
$$

The preheated fresh water temperature $T^{p h}$ of unbalanced flows must be calculated iteratively based on the fresh water mass flow and using the relations between mass flow, temperature difference and heat transfer coefficient $\mathrm{U}$ in $\mathrm{W} / \mathrm{m} 2 * \mathrm{~K}$, heat exchanger surface $\mathrm{A}$ in $\mathrm{m}^{2}$ and the logarithmic mean temperature difference dTm, expressed in K (Eq.(A.4)).

$$
\dot{Q}_{H E}=\dot{m}^{F W} \times c_{p} \times\left(T^{p h}-T^{F W}\right)=U \times A \times d T m
$$

The heat exchanger surface A can be obtained from the manufacturer. It is referred to the literature for the calculation procedure of the logarithmic mean temperature difference $\mathrm{dTm}$ and the heat transfer coefficient U (e.g. VDI Gesellschaft [48]), as the detailed description would be out of scope of the current urban-scale work.

\section{Configuration 2}

The preheated mass flow of configuration 2 corresponds to the shower mass flow. For balanced flows, the preheated water temperature $T^{p h}$ is obtained from heat exchanger efficiency $\varepsilon$, provided by certification institutions, e.g. KIWA in the Netherlands (www.kiwa.nl) or Passivhaus Institut in Germany (www.passiv.de), following Eq.(A.5). 


$$
\varepsilon=\frac{T^{p h}-T^{F W}}{T^{W W}-T^{F W}}
$$

\section{Configuration 3}

Concerning configuration 3 , the preheated mass flow corresponds to the fresh water flow, a function of the shower mass flow and the system temperatures (Eq.(A.6)).

$$
\dot{m}^{p h}=\dot{m}_{\text {shower }} \times \frac{\left(T^{H W}-T_{\text {shower }}\right)}{\left(T^{H W}-T^{p h}\right)}
$$

The preheated water temperature $T^{p h}$ is obtained by subtracting the minimum temperature difference dTmin from the waste water temperature (Eq.(A.7)).

$$
T^{p h}=T^{W W}-d T \min
$$

\section{AppendixB. Mass and temperature levels for grey heat recovery configurations}

\section{Configuration 4}

The hot water mass flow $\dot{m}_{e}^{H W}$ is proportional to the temperatures of the end-use $T_{e}$, hot water $T^{H W}$ and fresh water $T^{F W}$ as well as the end-use mass flow $\dot{m}_{e}$ (Eq.(B.1)).

$$
\dot{m}_{e}^{H W}=\dot{m}_{e} \times \frac{\left(T_{e}-T^{F W}\right)}{\left(T^{H W}-T^{F W}\right)}
$$

The grey water tank temperature is obtained from the energy conservation equation considering the sum of the products between temperature and mass of the various grey water streams and the tank water mass (Eq.(B.2)).

$$
T^{\text {tank }}=\frac{\sum_{G W}\left(T^{G W} \times m^{G W}\right)}{m^{\text {tank }}}
$$

The grey water thermal power is calculated with the tank energy content potentially rejected at sewer temperature, over a period of one hour (Eq. (B.3)).

$$
\dot{Q}^{\text {tank }}=\frac{m^{\text {tank }} \times c_{p} \times\left(T^{\text {tank }}-T^{\text {sewer }}\right)}{3600}
$$

\section{Configuration 5}

The thermal load $\dot{Q}_{e}$ of the various DHW end-uses e is obtained by aggregating the daily energy requirements considering the occupant $x_{o c c}$ or household numbers of the building. Eq.(B.4) is given as example for the load of DHW end-uses related to occupant use (e.g. showering, bathing).

$$
\dot{Q}_{e}=\frac{\sum_{x_{o c c}}\left(\dot{m}_{e} \times d_{e} \times f_{e}\right) \times c_{p} \times\left(T_{e}-T^{F W}\right)}{3600}
$$

\section{Configuration 6}

The thermal power of a grey water stream $\dot{Q}^{G W}$ is calculated with Eq.(B.5), considering the sewer temperature $T^{\text {sewer }}$ as final temperature.

$$
\dot{Q}^{G W}=\frac{\sum_{x_{o c c}}\left(\dot{m}^{G W} \times d_{e} \times f_{e}\right) \times c_{p} \times\left(T^{G W}-T^{\text {sewer }}\right)}{3600}
$$




\section{Bibliography}

[1] European Commission, Energy Efficiency and its contribution to energy security and the 2030 Framework for climate and energy policy - COM(2014) 520 final, URL http://ec.europa.eu/ energy/efficiency/events/doc/2014_eec_communication_adopted.pdf, 2014.

[2] European Commission, Statistical Pocketbook 2015, doi: $\backslash$ bibinfo $\{$ doi $\}\{10.2833 / 77358\}$, URL https://ec.europa.eu/energy/sites/ener/files/documents/PocketBook_ENERGY_2015\% 20PDF\%20final.pdf, 2015.

[3] Enerdata, ODYSSEE database on energy efficiency data \& indicators, URL http: //www.indicators.odyssee-mure.eu/energy-efficiency-database.html, last accessed: 08/02/2016, 2016.

[4] F. Meggers, H. Leibundgut, The potential of wastewater heat and exergy: Decentralized hightemperature recovery with a heat pump, Energy and Buildings 43 (4) (2011) 879 - 886, ISSN 0378-7788, doi: \bibinfo $\{$ doi $\}$ \{http://dx.doi.org/10.1016/j.enbuild.2010.12.008\}, URL http: //www.sciencedirect.com/science/article/pii/S0378778810004287.

[5] A. Bertrand, A. Mastrucci, N. Schueler, R. Aggoune, F. Marechal, Characterisation of domestic hot water end-uses for integrated urban thermal energy assessment and optimisation, Applied Energy doi: \bibinfo\{doi\}\{http://dx.doi.org/10.1016/j.apenergy.2016.02.107\}, in press.

[6] P. Eslami-nejad, M. Bernier, Impact of grey water heat recovery on the electrical demand of domestic hot water heaters, in: 11th International Building Performance Simulation Association Conference, Glasgow, Scotland, July 27-30, 2009, 2009.

[7] L. Wong, K. Mui, Y. Guan, Shower water heat recovery in high-rise residential buildings of Hong Kong, Applied Energy 87 (2) (2010) 703 - 709, ISSN 0306-2619, doi: \bibinfo\{doi\}\{http: //dx.doi.org/10.1016/j.apenergy.2009.08.008\}, URL http://www. sciencedirect.com/science/ article/pii/S0306261909003225.

[8] Y. X. Guo, Y. L. Cai, S. Q. Liang, W. Chen, Experimental Study on a Shower Waste Water Heat Recovery Device in Buildings, Applied Mechanics and Materials 226-228 (2012) 2402-2406, doi: \bibinfo\{doi $\}\{10.4028 /$ www.scientific.net/AMM.226-228.2402\}.

[9] A. McNabola, K. Shields, Efficient drain water heat recovery in horizontal domestic shower drains, Energy and Buildings 59 (2013) 44 - 49, ISSN 0378-7788, doi:〈bibinfo\{doi\}\{http://dx.doi.org/ 10.1016/j.enbuild.2012.12.026\}, URL http://www.sciencedirect.com/science/article/pii/ S0378778812006755.

[10] L. Liu, L. Fu, Y. Jiang, Application of an exhaust heat recovery system for domestic hot water, Energy 35 (3) (2010) 1476 - 1481, ISSN 0360-5442, doi: \bibinfo\{doi\}\{http://dx.doi.org/ 10.1016/j.energy.2009.12.004\}, URL http://www.sciencedirect.com/science/article/pii/ S0360544209005246.

[11] W. Chen, S. Liang, Y. Guo, K. Cheng, X. Gui, D. Tang, Investigation on the thermal performance and optimization of a heat pump water heater assisted by shower waste water, Energy and Buildings 64 (2013) 172 - 181, ISSN 0378-7788, doi: \bibinfo\{doi\}\{http://dx.doi.org/ 10.1016/j.enbuild.2013.04.021\}, URL http://www.sciencedirect.com/science/article/pii/ S0378778813002740. 
[12] J. Wallin, J. Claesson, Analyzing the efficiency of a heat pump assisted drain water heat recovery system that uses a vertical inline heat exchanger, Sustainable Energy Technologies and Assessments 8 (2014) 109 - 119, ISSN 2213-1388, doi: $\backslash$ bibinfo $\{$ doi $\}\{$ http://dx. doi.org/10.1016/j.seta.2014.08.003\}, URL http://www.sciencedirect.com/science/article/ $\mathrm{pii} / \mathrm{S} 2213138814000733$

[13] J. Dong, Z. Zhang, Y. Yao, Y. Jiang, B. Lei, Experimental performance evaluation of a novel heat pump water heater assisted with shower drain water, Applied Energy 154 (2015) 842 850, ISSN 0306-2619, doi: \bibinfo\{doi\}\{http://dx.doi.org/10.1016/j.apenergy.2015.05.044\}, URL http://www.sciencedirect.com/science/article/pii/S0306261915006546.

[14] A. Hepbasli, E. Biyik, O. Ekren, H. Gunerhan, M. Araz, A key review of wastewater source heat pump (WWSHP) systems, Energy Conversion and Management 88 (2014) 700 - 722, ISSN 01968904, doi: \bibinfo\{doi\}\{http://dx.doi.org/10.1016/j.enconman.2014.08.065\}, URL http://www . sciencedirect.com/science/article/pii/S0196890414007900.

[15] S. Kordana, D. Slys, J. Dziopak, Rationalization of water and energy consumption in shower systems of single-family dwelling houses, Journal of Cleaner Production 82 (2014) 58 - 69, ISSN 0959-6526, doi: \bibinfo\{doi\}\{http://dx.doi.org/10.1016/j.jclepro.2014.06.078\}, URL http: //www.sciencedirect.com/science/article/pii/S0959652614006660.

[16] L. Girardin, F. Marechal, M. Dubuis, N. Calame-Darbellay, D. Favrat, EnerGis: A geographical information based system for the evaluation of integrated energy conversion systems in urban areas, Energy 35 (2) (2010) 830 - 840, ISSN 0360-5442, doi:〈bibinfo\{doi\}\{http://dx.doi.org/ 10.1016/j.energy.2009.08.018\}, URL http://www.sciencedirect.com/science/article/pii/ S0360544209003582.

[17] A. Omu, R. Choudhary, A. Boies, Distributed energy resource system optimisation using mixed integer linear programming, Energy Policy 61 (2013) 249 - 266, ISSN 0301-4215, doi: \bibinfo\{doi\}\{http://dx.doi.org/10.1016/j.enpol.2013.05.009\}, URL http://www . sciencedirect.com/science/article/pii/S0301421513003418.

[18] L. Gerber, S. Fazlollahi, F. Marechal, A systematic methodology for the environomic design and synthesis of energy systems combining process integration, Life Cycle Assessment and industrial ecology, Computers \& Chemical Engineering 59 (2013) 2 - 16, ISSN 00981354, doi: \bibinfo\{doi\}\{http://dx.doi.org/10.1016/j.compchemeng.2013.05.025\}, URL http: //www.sciencedirect.com/science/article/pii/S0098135413001890, selected papers from ESCAPE-22 (European Symposium on Computer Aided Process Engineering - 22), 17-20 June 2012, London, $\{\mathrm{UK}\}$.

[19] S. Fazlollahi, G. Becker, F. Maréchal, Multi-objectives, multi-period optimization of district energy systems: II - Daily thermal storage, Computers \& Chemical Engineering 71 (2014) 648 662, ISSN 0098-1354, doi: \bibinfo\{doi\}\{http://dx.doi.org/10.1016/j.compchemeng.2013.10.016\}, URL http://www.sciencedirect.com/science/article/pii/S0098135413003384.

[20] M. Jennings, D. Fisk, N. Shah, Modelling and optimization of retrofitting residential energy systems at the urban scale, Energy 64 (2014) 220 - 233, ISSN 0360-5442, doi: \bibinfo\{doi $\}$ http: //dx.doi.org/10.1016/j.energy.2013.10.076\}, URL http://www.sciencedirect.com/science/ article/pii/S0360544213009432.

[21] P. S. Varbanov, J. J. Klemes, Integration and management of renewables into Total Sites with variable supply and demand, Computers and Chemical Engineering 35 (9) (2011) 1815 - 1826, ISSN 0098-1354, doi: \bibinfo\{doi\}\{http://dx.doi.org/10.1016/j.compchemeng.2011.02.009\}, URL 
http://www.sciencedirect.com/science/article/pii/S0098135411000718, energy Systems Engineering.

[22] C. M. Leidl, W. D. Lubitz, Comparing domestic water heating technologies, Technology in Society 31 (3) (2009) 244 - 256, ISSN 0160-791X, doi: \bibinfo\{doi\}\{http://dx.doi.org/ 10.1016/j.techsoc.2009.06.005\}, URL http://www.sciencedirect.com/science/article/pii/ S0160791X09000591.

[23] L. Ni, S. Lau, H. Li, T. Zhang, J. Stansbury, J. Shi, J. Neal, Feasibility study of a localized residential grey water energy-recovery system, Applied Thermal Engineering 39 (2012) 53 62, ISSN 1359-4311, doi: \bibinfo\{doi\}\{http://dx.doi.org/10.1016/j.applthermaleng.2012.01.031\}, URL http://www.sciencedirect.com/science/article/pii/S1359431112000403.

[24] A. Bertrand, R. Aggoune, F. Maréchal, In-building waste water heat recovery: an urban scale method for energy saving assessments, in: 29th international conference on Efficiency, Cost, Optimization, Simulation and Environmental Impact of Energy Systems (ECOS), Portoroz, Slovenia, 2016.

[25] Passivhaus Institut, Kriterien und Algorithmen für die Zertifizierte Passivhaus-Komponente DuschwasserWärmerückgewinnung, Tech. Rep., Passivhaus Institut, URL http://www.passiv . de/downloads/03_zertifizierungskriterien_ww_wrg_de.pdf, in German, last accessed: $09 / 12 / 2015,2014$.

[26] D. Saker, M. Vahdati, P. Coker, S. Millward, Assessing the benefits of domestic hot fill washing appliances, Energy and Buildings 93 (2015) 282 - 294, ISSN 0378-7788, doi: \bibinfo\{doi $\{$ http: //dx.doi.org/10.1016/j.enbuild.2015.02.027\}, URL http://www.sciencedirect.com/science/ article/pii/S0378778815001322.

[27] M. D. Paepe, E. Theuns, S. Lenaers, J. V. Loon, Heat recovery system for dishwashers, Applied Thermal Engineering 23 (6) (2003) 743 - 756, ISSN 1359-4311, doi: \bibinfo\{doi\}\{http:// dx.doi.org/10.1016/S1359-4311(03)00016-4\}, URL http://www.sciencedirect.com/science/ article/pii/S1359431103000164.

[28] E. J. M. Blokker, J. H. G. Vreeburg, J. C. Van Dijk, Simulating Residential Water Demand with a Stochastic End-Use Model., Journal of Water Resources Planning \& Management 136 (1) (2010) 19 - 26, ISSN 07339496, URL http://ascelibrary.org/doi/abs/10.1061/(ASCE)WR. 1943-5452.0000002.

[29] D. Hoak, D. Parker, A. Hermelink, How Energy Efficient Are Modern Dishwashers, in: American Council for an Energy Efficient Economy 2008 - Summer Study on Energy Efficiency in Buildings, Washington, U.S.A., August 2008, URL http://www.fsec.ucf.edu/en/publications/ pdf/FSEC-CR-1772-08.pdf, last accessed: 18/01/2016, 2008.

[30] A. Hauer, F. Fischer, Open Adsorption System for an Energy Efficient Dishwasher, Chemie Ingenieur Technik 83 (1-2) (2011) 61-66, ISSN 1522-2640, doi: $\backslash$ bibinfo $\{$ doi $\}\{10.1002 /$ cite.201000197 $\}$, URL http://dx.doi.org/10.1002/cite.201000197.

[31] U. Persson, S. Werner, District heating in sequential energy supply, Applied Energy 95 (0) (2012) 123 - 131, ISSN 0306-2619, doi: \bibinfo\{doi\}\{http://dx.doi.org/10.1016/j.apenergy.2012.02.021\}, URL http://www.sciencedirect.com/science/article/pii/S0306261912001158.

[32] P. Bengtsson, J. Berghel, R. Renstroem, A household dishwasher heated by a heat pump system using an energy storage unit with water as the heat source, International Journal of Refrigeration 
49 (2015) 19 - 27, ISSN 0140-7007, doi: bibinfo\{doi\}\{http://dx.doi.org/10.1016/j.ijrefrig.2014.10. 012\}, URL http://www.sciencedirect.com/science/article/pii/S0140700714002849.

[33] S. W. Jeong, D. H. Lee, Drying performance of a dishwasher with internal air circulation, Korean Journal of Chemical Engineering 31 (9) (2014) 1518-1521, ISSN 0256-1115, doi: $\backslash$ bibinfo $\{$ doi $\}\{10$. 1007/s11814-014-0194-0\}, URL http://dx.doi.org/10.1007/s11814-014-0194-0.

[34] C. P. Richter, Usage of dishwashers: observation of consumer habits in the domestic environment, International Journal of Consumer Studies 35 (2) (2011) 180-186, ISSN 14706431, doi: \bibinfo\{doi\}\{10.1111/j.1470-6431.2010.00973.x\}, URL http://dx.doi.org/10.1111/ j.1470-6431.2010.00973.x.

[35] C. Pakula, R. Stamminger, Electricity and water consumption for laundry washing by washing machine worldwide, Energy Efficiency 3 (4) (2010) 365-382, doi: $\backslash$ bibinfo $\{$ doi $\}\{10.1007 /$ s12053-009-9072-8\}.

[36] T. Persson, Dishwasher and washing machine heated by a hot water circulation loop, Applied Thermal Engineering 27 (1) (2007) 120 - 128, ISSN 1359-4311, doi: bibinfo\{doi\}\{http://dx.doi.org/10. 1016/j.applthermaleng.2006.05.005\}, URL http://www.sciencedirect.com/science/article/ $\mathrm{pii} / \mathrm{S} 1359431106001694$.

[37] B. Linnhoff, J. R. Flower, Synthesis of heat exchanger networks: I. Systematic generation of energy optimal networks, AIChE Journal 24 (4) (1978) 633-642, ISSN 1547-5905, doi: $\backslash$ bibinfo $\{$ doi $\}\{10$. 1002/aic.690240411\}, URL http://dx.doi.org/10.1002/aic.690240411.

[38] D. Slys, S. Kordana, Financial analysis of the implementation of a Drain Water Heat Recovery unit in residential housing, Energy and Buildings 71 (2014) 1 - 11, ISSN 03787788, doi: $\backslash$ bibinfo\{doi\}\{http://dx.doi.org/10.1016/j.enbuild.2013.11.088\}, URL http://www . sciencedirect.com/science/article/pii/S0378778813008062.

[39] Passivhaus Institut, Component database - Drain water heat recovery, URL http://database. passivehouse.com/en/components/drain_water_heat_recovery, last accessed: 18/04/2016, 2016.

[40] K. Tanha, A. S. Fung, R. Kumar, Performance of two domestic solar water heaters with drain water heat recovery units: Simulation and experimental investigation, Applied Thermal Engineering 90 (2015) 444 - 459, ISSN 1359-4311, doi: \bibinfo\{doi\}\{http://dx.doi.org/10.1016/ j.applthermaleng.2015.07.038\}, URL http://www.sciencedirect.com/science/article/pii/ S135943111500722X.

[41] J. Schnieders, D5.1.12 Drain water heat recovery in retrofits, Tech. Rep., Passive House Institute, URL http://europhit.eu/sites/europhit.eu/files/Design\%20briefs/EuroPHit_D5.1.12_ DWHR_PHI_b.pdf, last accessed: 18/04/2016, 2015.

[42] M. Brand, J. E. Thorsen, S. Svendsen, Numerical modelling and experimental measurements for a low-temperature district heating substation for instantaneous preparation of DHW with respect to service pipes, Energy 41 (1) (2012) 392 - 400, ISSN 0360-5442, doi: \bibinfo\{doi\}\{http://dx.doi. org/10.1016/j.energy.2012.02.061\}, URL http://www.sciencedirect.com/science/article/ pii/S0360544212001752, 23rd International Conference on Efficiency, Cost, Optimization, Simulation and Environmental Impact of Energy Systems, \{ECOS\} 2010.

[43] E.-R. Schramek (Ed.), Taschenbuch für Heizung und Klimatechnik 07/08, Oldenbourg Industrieverlag München, 73 edn., 2007. 
685

686

687

688

689

690

691

692

693

on

695

696

697

[44] M. Gaderer, Wärmeversorgung mit fester Biomasse bei kleiner Leistung, Ph.D. thesis, Technische Universtiät München, URL https://mediatum.ub.tum.de/doc/630149/630149.pdf, 2007.

[45] PostgreSQL, PostgreSQL: an open source object-relational database system, URL http://www . postgresql.org, 2015.

[46] Luxemburgish Parliament, Règlement grand-ducal du 26 mai 2014 modifiant 1. le règlement grand-ducal modifié du 30 novembre 2007 concernant la performance énergétique des bâtiments d'habitation; 2. le règlement grand-ducal modifié du 31 août 2010 concernant la performance énergétique des bâtiments fonctionnels; et 3. le règlement grand-ducal du 27 février 2010 concernant les installations à gaz, 2014.

[47] H. Becker, Methodology and thermo-economic optimization for integration of industrial heat pumps, Ph.D. thesis, EPFL, Lausanne, Switzerland, URL http://infoscience.epfl.ch/ record/175150/files/EPFL_TH5341.pdf, 2012.

[48] VDI Gesellschaft, VDI-Wärmeatlas, Springer Berlin Heidelberg, 10th edn., 2006. 